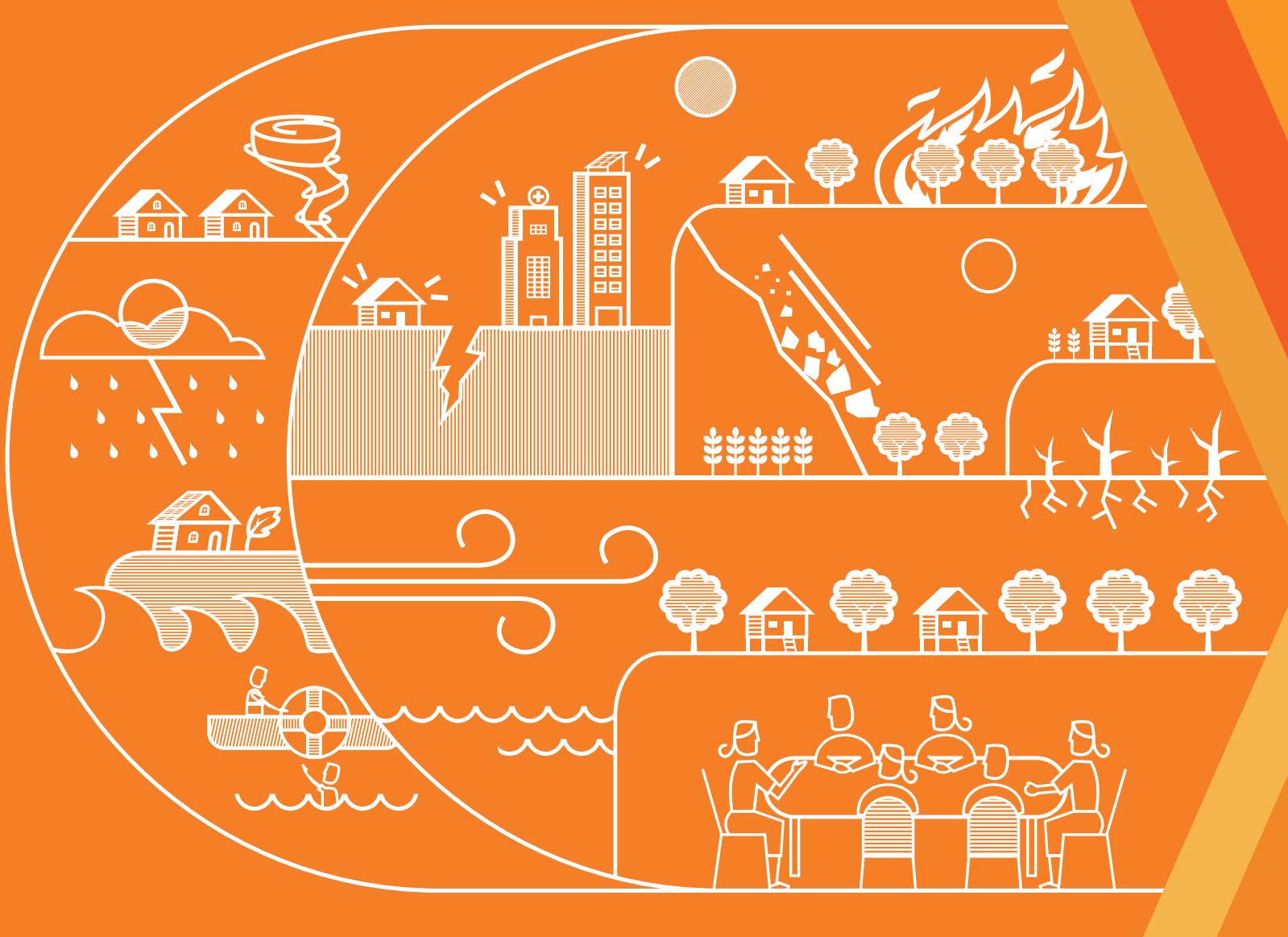

\title{
NATURAL HAZARD DATA
}

A Practical Guide 
NATURAL HAZARD DATA A Practical Guide NOVEMBER 2017 


\author{
(c) 2017 Asian Development Bank \\ 6 ADB Avenue, Mandaluyong City, 1550 Metro Manila, Philippines \\ Tel +632632 4444; Fax+6326362444 \\ www.adb.org \\ Some rights reserved. Published in 2017. \\ ISBN 978-92-9261-012-8 (Print), 978-92-9261-013-5 (PDF) \\ Publication Stock No. TIM178692-2 \\ DOI: http://dx.doi.org/10.22617/TIM178692-2
}

The views expressed in this publication are those of the authors and do not necessarily reflect the views and policies of the Asian Development Bank (ADB) or its Board of Governors or the governments they represent.

ADB does not guarantee the accuracy of the data included in this publication and accepts no responsibility for any consequence of their use. The mention of specific companies or products of manufacturers does not imply that they are endorsed or recommended by $\mathrm{ADB}$ in preference to others of a similar nature that are not mentioned.

By making any designation of or reference to a particular territory or geographic area, or by using the term "country" in this document, $A D B$ does not intend to make any judgments as to the legal or other status of any territory or area.

This work is available under the Creative Commons Attribution 3.0 IGO license (CC BY 3.0 IGO)

https://creativecommons.org/licenses/by/3.0/igo/. By using the content of this publication, you agree to be bound by the terms of this license. For attribution, translations, adaptations, and permissions, please read the provisions and terms of use at https://www.adb.org/terms-use\#openaccess

This CC license does not apply to non-ADB copyright materials in this publication. If the material is attributed to another source, please contact the copyright owner or publisher of that source for permission to reproduce it. ADB cannot be held liable for any claims that arise as a result of your use of the material.

Please contact pubsmarketing@adb.org if you have questions or comments with respect to content, or if you wish to obtain copyright permission for your intended use that does not fall within these terms, or for permission to use the ADB logo.

Notes:

In this publication, "\$” refers to US dollars.

ADB recognizes "Vietnam" as Viet Nam.

Corrigenda to ADB publications may be found at http://www.adb.org/publications/corrigenda 


\section{Contents}

Acknowledgments $\quad$ iv

Abbreviations $v$

Executive Summary vi

1 Introduction 1

2 Key Concepts 2

A. Natural Hazards: One Component of Disaster Risk

B. Measuring Natural Hazards: Frequency, Intensity, Location

C. Understanding Return Periods

D. The Role of Historical Catalogs

E. Probabilistic and Deterministic Approaches to Natural Hazards

F. Climate Change and Natural Hazards

3 Factors to Consider When Assessing Natural Hazard Datasets for Operational Purposes
A. Introduction
B. Scale and Resolution
C. Temporality
D. Data Gaps
E. Authoritativeness
F. Licensing and Open Data
G. Data Formats

4 Discussion of Natural Hazard Data by Type

A. Geophysical

1. Earthquake

2. Tsunami

3. Volcano

B. Weather

1. Tropical Cyclone

2. Flood (Riverine)

3. Landslide

4. Drought

5 Other Data Sources

6 Recommendations for Managing Natural Hazard Data

Created by ADB

Country Case Study: Natural Hazard Data in Nepal 


\section{Acknowledgments}

This practical guide was prepared under the regional technical assistance project Development of Guidance Materials and Screening Tools for Incorporating Disaster Risk Concerns in Country Partnership Strategy and Project Preparation (TA 8752-REG) of the Asian Development Bank (ADB). The project was implemented under the overall guidance of Charlotte Benson, principal disaster risk management specialist, Sustainable Development and Climate Change Department (SDCC). This document was prepared by Robert Soden (consultant).

The document benefited significantly from comments received from the following ADB staff: Rexel Abrigo, climate change officer (Climate Change Adaptation), SDCC; Mary Jane David, senior public management officer (Disaster Risk Management), SDCC; Erik Kjaergaard, disaster risk management specialist, South Asia Department; Cinzia Losenno, former senior climate change specialist (Climate Change Adaptation), SDCC; Anil Pokhrel, former disaster risk management specialist, SDCC; Nathan Rive, climate change specialist, Central and West Asia Department; Bhuneshwar Prasad Sah, infrastructure specialist (GIS), SDCC; Yasmin Siddiqi, principal water resources specialist, SDCC; Arghya Sinha Roy, senior disaster risk management specialist, SDCC; Binsar Tambunan, former lead portfolio management specialist/project administration unit head, Central and West Asia Department; Hanna Uusimaa, climate change specialist, Pacific Department; and Tadayoshi Yahata, infrastructure specialist, SDCC.

External comments from Abigail Baca (World Bank), David Lallemant (Co-Risk Labs), Xianfu Lu (consultant), and Jeremy Wetterwald (REACH Initiative) were also gratefully received.

The Nepal country case study annex was much enhanced by insights and comments from Lok Adhikari (Nepal National Seismological Centre), Nama Budhathoki (Kathmandu Living Labs), Deo Raj Gurung (International Centre for Integrated Mountain Development), Sumeer Koirala (Nepal Ministry of Land Reform and Management), Shashish Maharajan (Kathmandu University), Niru Pradhan (Nepal Red Cross), Sushil Rajbhandari (Nepal National Geographic Information Infrastructure Programme), and Tom Zearley (United States Agency for International Development).

Grendel Saldevar-Perez, senior operations assistant, SDCC, skillfully managed budgetary and contractual matters, and provided invaluable administrative support. The document was proofread by Ricardo Chan and Kae Sugawara and the layout designed by Rocilyn Locsin Laccay.
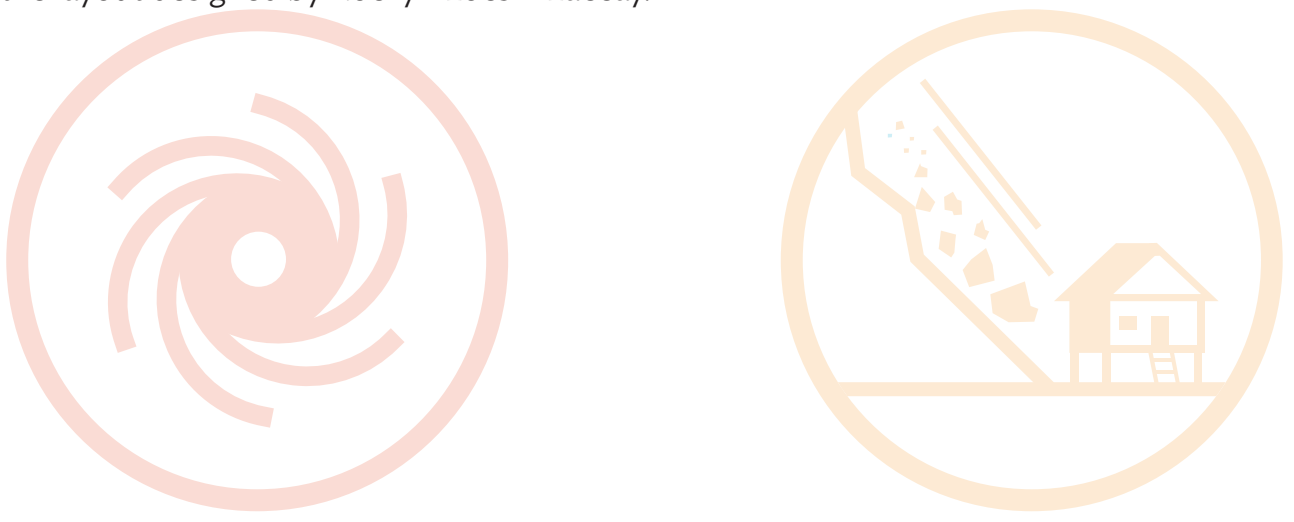


\section{Abbreviations}

$\begin{array}{ll}\text { ADB } & \text { Asian Development Bank } \\ \text { cm } & \text { centimeter } \\ \text { DEM } & \text { digital elevation model } \\ \text { DMC } & \text { developing member country } \\ \text { DRM } & \text { disaster risk management } \\ \text { GAR } & \text { Global Assessment Report on Disaster Risk Reduction } \\ \text { GCM } & \text { global climate model } \\ \text { GEM } & \text { Global Earthquake Model } \\ \text { GIS } & \text { geographic information system } \\ \text { IBTrACS } & \text { International Best Track Archive for Climate Stewardship } \\ \text { ICIMOD } & \text { International Centre for Integrated Mountain Development } \\ \text { IPCC } & \text { Intergovernmental Panel on Climate Change } \\ \text { km } & \text { kilometer } \\ \text { km } & \text { square kilometer } \\ \text { m } & \text { meter } \\ \text { NOAA } & \text { United States National Oceanic and Atmospheric Administration } \\ \text { NSC } & \text { National Seismological Center (Nepal) } \\ \text { OpenDRI } & \text { Open Data for Resilience Initiative } \\ \text { PDC } & \text { Pacific Disaster Center } \\ \text { PGA } & \text { peak ground acceleration } \\ \text { SVI } & \text { standard vegetation index } \\ \text { TA } & \text { technical assistance } \\ \text { UNISDR } & \text { United Nations Office for Disaster Risk Reduction } \\ \text { VHI } & \text { volcano hazard index } \\ & \\ \end{array}$
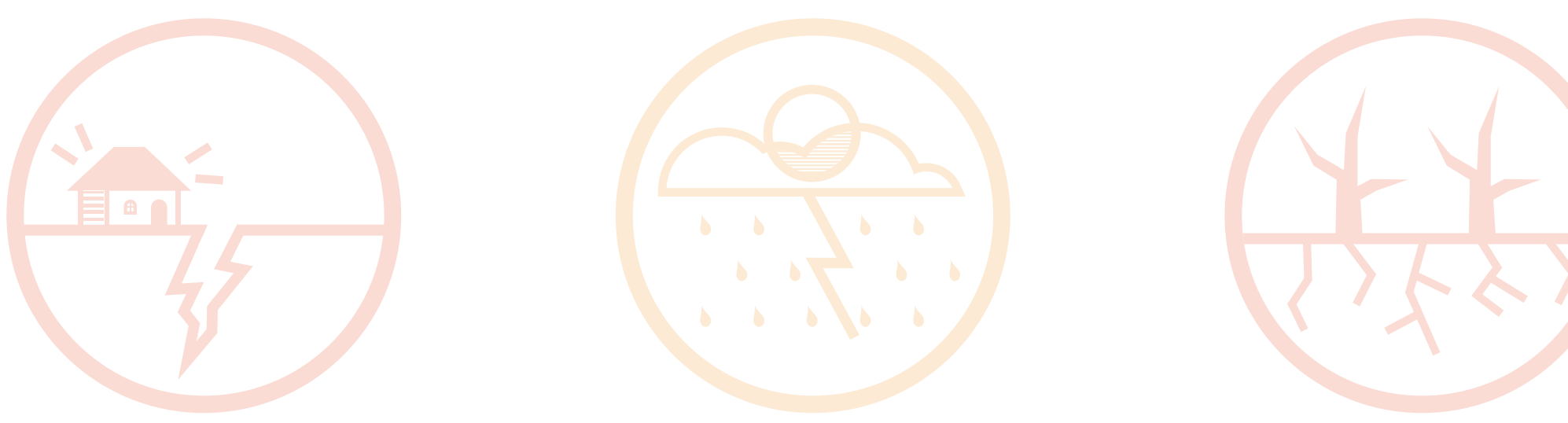


\section{Executive Summary}

Disasters pose a significant threat to the sustainability of development projects and investments. At the same time, many development actions provide opportunities to strengthen disaster resilience. Reflecting this, the integration of disaster risk reduction into development forms one of the three key principles of the Operational Plan for Integrated Disaster Risk Management, 2014-2020 of the Asian Development Bank (ADB).

This document is intended to support the application of this principle by providing guidance to ADB staff on the identification and application of robust natural hazard data for use in integrating disaster risk considerations in country partnership strategies and individual projects. Natural hazards form one of the three components that determine disaster risk. They fall into two categories reflecting their underlying natural causes: geophysical hazards, such as earthquakes, tsunamis, and volcanic eruptions; and hydrometeorological hazards or extreme weather events, such as floods, drought, and tropical cyclones. Assessments of disaster risk take into account the frequency, intensity, and location of potential hazard events and combine this information with data on the exposure of people, infrastructure, and other assets to those hazards, as well as the level and nature of vulnerability of those people and assets. This document supports nonhazard specialists in developing terms of reference for and overseeing hazard and disaster risk assessment technical experts.

It begins by outlining the rationale for this practical guide in further detail. Section 2 provides a general introduction to key concepts and ideas related to natural hazard and disaster risk information. Section 3 provides recommendations on factors to consider in deciding between potential natural hazard datasets, including licensing, scale and/or resolution, and authoritativeness. Section 4 covers six major categories of weather and geophysical hazard, discussing common approaches to the measurement and categorization of each hazard, and highlighting key international datasets along with their uses and limitations. Section 5 provides guidance on other data sources. Finally, Section 6 closes with a brief discussion of best practices and recommendations on the management and sharing of natural hazard information created with ADB's support. The appendix presents a sample country natural hazard data report for Nepal to provide further guidance to ADB teams that are seeking to collate and access natural hazard and disaster risk information at a country level.

The practical guide was prepared as part of a wider capacity development technical assistance (TA) project, Development of Guidance Materials and Screening Tools for Incorporating Disaster Risk Concerns in Country Partnership Strategy and Project Preparation (TA 8752-REG), financed by ADB's Technical Assistance Special Fund. ${ }^{2}$ The TA project is intended to secure the systematic consideration of disaster risk concerns in ADB's country partnership strategies and projects. Two companion practical guides focus on integrating disaster risk considerations into country partnership strategies ${ }^{3}$ and on disaster risk assessment at the project level. ${ }^{4}$ The TA project also supports the modification of an interactive online project climate risk screening tool-AWARE- used by ADB to integrate geological hazards, enhance weather-related hazard components, and augment screening output recommendations regarding disaster risk management.

ADB. 2014. Operational Plan for Integrated Disaster Risk Management, 2014-2020. Manila

ADB. 2014. Technical Assistance for Development of Guidance Materials and Screening Tools for Incorporating Disaster Risk Concerns in Country Partnership Strategy and Project Preparation. Manila (TA 8752-REG).

ADB. 2017. Disaster Risk Management and Country Partnership Strategies: A Practical Guide. Manila.

ADB. 2017. Disaster Risk Assessment for Project Preparation: A Practical Guide. Manila. 


\section{Introduction}

Disaster and climate risk are a major challenge in Asia and the Pacific. The region faces significant exposure to every major type of geophysical and weather-related hazard, and the countries of Asia and the Pacific consistently rank among the most at risk from the human and economic impacts of natural hazards. This risk is increasing. Rapid urbanization, including billions of dollars in planned and unplanned infrastructure investments in hazard-prone areas with insufficient regard to disaster risk, is creating new exposure and vulnerabilities. At the same time, climate change is impacting the frequency and severity of some natural hazards. Disaster and climate risk is, therefore, a critical sustainable development issue and is becoming an increasingly prominent topic in the work of the Asian Development Bank (ADB).

The foundation of effective disaster risk management (DRM) is information. The Sendai Framework for Disaster Risk Reduction 2015-2030 identifies understanding disaster risk as one of its key priorities. ${ }^{1}$ Several positive trends are contributing to the increasing potential for ADB staff to make effective use of robust hazard information in their project design. First, more data are becoming available at national levels as governments around the world develop or improve upon national spatial data infrastructure, hydrometeorological agency capabilities, and other systems for creating and maintaining information. DRM practitioners can capitalize on strong natural hazard models that can provide a good basis for risk assessments. Second, thanks to efforts from a number of international and scientific organizations, such as the European Space Agency, the Japan Aerospace Exploration Agency, and the United States National Aeronautics and Space Administration, a growing number of global datasets are improving in coverage and resolution, and increasingly being made publicly available for use in disaster risk modeling. Third, the move toward open data, promoted by organizations such as the Open Government Partnership ${ }^{2}$ and the World Bank's Open Data for Resilience Initiative (OpenDRI), ${ }^{3}$ is further helping to ensure that new and existing natural hazard data are widely available. Finally, a growing number of free and open source software tools are being developed to make natural hazard data more usable and accessible to nonexperts. ${ }^{4}$ The Oasis Platform for Catastrophe and Climate Change Risk Assessment and Adaptation, for instance, is enhancing access to transparent and standardized analytics, and is developing online training modules for modelers and model users. ${ }^{5}$

The specific purpose of this practical guide on natural hazard information is to provide ADB project officers with a basic understanding of natural hazards, the nature and purpose of hazard mapping and disaster risk assessments, and the availability and sources of related data and information for use in taking disaster risk into account in project design. In many cases, the assistance of technical experts will still be required when assessing and interpreting various datasets. However, this guide should provide nonhazard specialists with an understanding of many of the concepts and issues related to the use of natural hazard information in country programming and project design, support ADB staff in developing terms of reference for and overseeing hazard and disaster risk technical experts, and ensure that disaster risk is adequately addressed in ADB country programs and projects.

\footnotetext{
United Nations. 2015. Sendai Framework for Disaster Risk Reduction 2015-2030. New York

See Open Government Partnership. http://www.opengovpartnership.org/

See Open Data for Resilience Initiative. https://opendri.org/

For example, the InaSafe tool (http://inasafe.org/) developed by the Government of Indonesia.

See Oasis Platform for Catastrophe and Climate Change Risk Assessment and Adaptation http://www.oasislmf.org/
} 


\section{Key Concepts}

\section{A. Natural Hazards: One Component of Disaster Risk}

Disasters are produced by complex interactions between naturally occurring hazards, such as earthquakes or powerful tropical cyclones; the exposure of people, infrastructure, and other assets to those hazards; and the level and nature of vulnerability of those people and assets. Where and how infrastructure and other assets are built as well as the ability of different population groups to withstand and recover from shocks and stresses help shape the nature and level of disaster risk. A simple framing of this relationship is the often-used function

$$
\text { Disaster risk }=f\left(p\left(h_{i}\right), e, v\right)
$$

where disaster risk is a function $f$ of multiple variables: $p\left(h_{i}\right)$, a probabilistic function of a given natural hazard of varying intensity in a particular location; e, exposure; and v, vulnerability. This equation forms the basis for disaster risk assessment, as illustrated by the steps undertaken for a disaster risk assessment of the building stock in Papua New Guinea presented in Figure 1. The figure shows mapped outputs of (i) the hazard analysis, in this example focusing on a 1-in-100-year earthquake (section 2.E on scenario-based or deterministic hazard analysis); (ii) the cataloguing of exposed assets, in this case focusing on critical infrastructure; and (iii) the resulting disaster risk assessment; that is, the degree of loss for a given peak ground acceleration, also taking into account the vulnerability of the exposed assets. 
Figure 1: Disaster Risk Assessment in Papua New Guinea

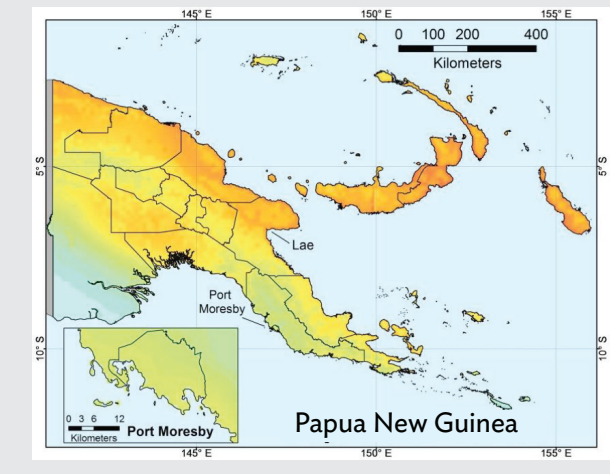

\section{NATURAL HAZARD}

Probability of a natural hazard scenario. In this case, peak ground acceleration for a given 1-in-100-year return period earthquake event.
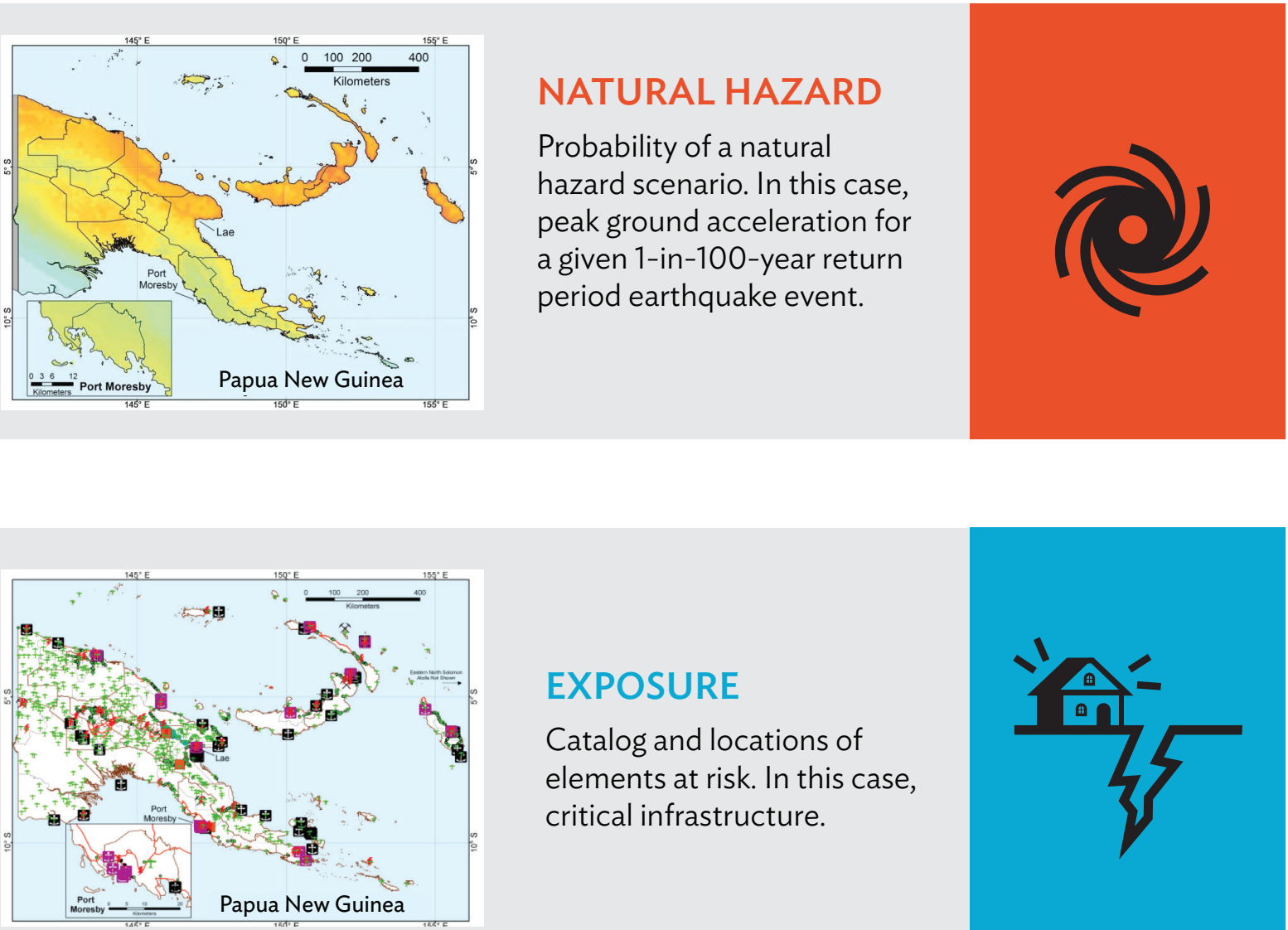

\section{EXPOSURE}

Catalog and locations of elements at risk. In this case, critical infrastructure.
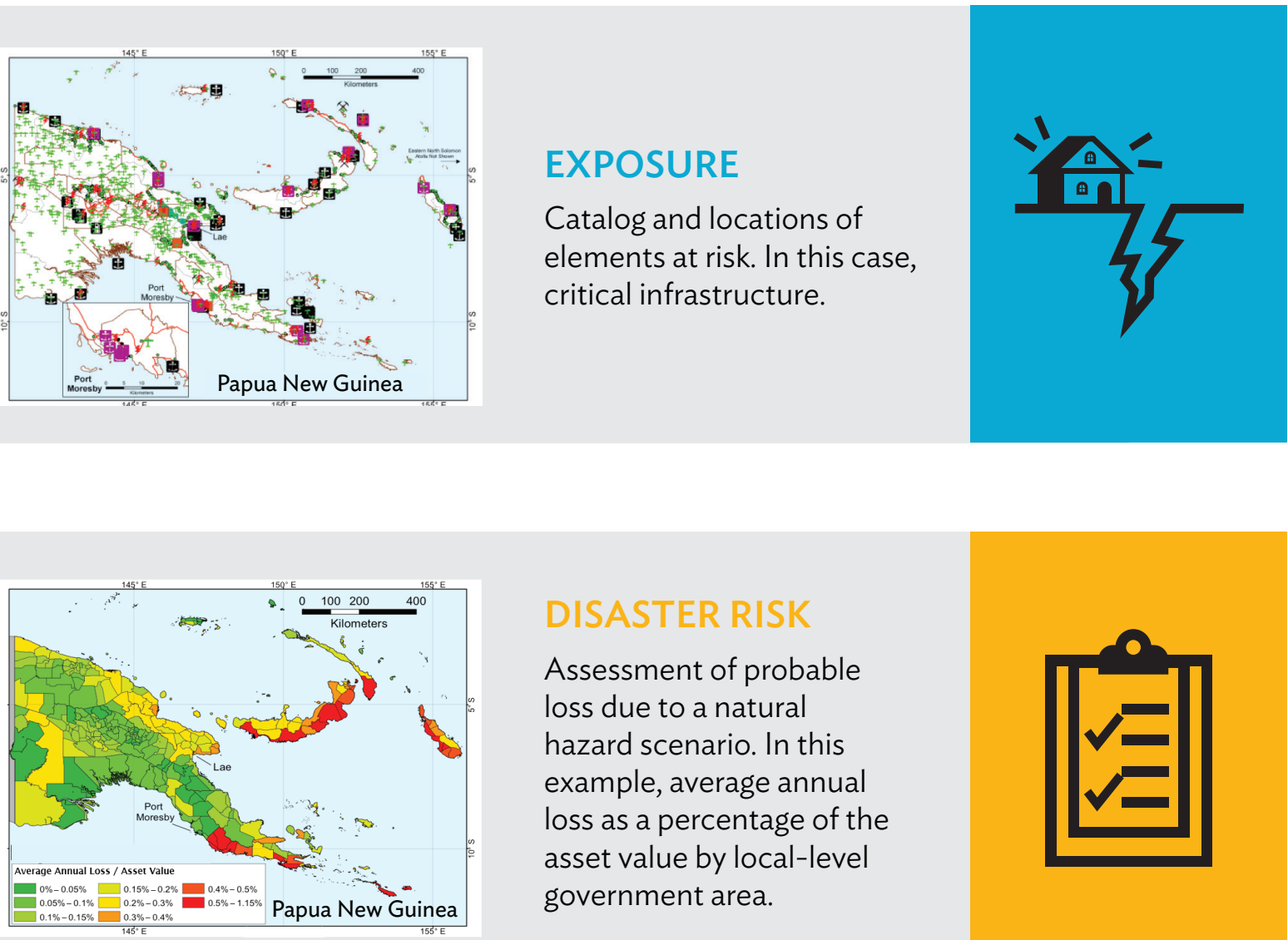

\section{DISASTER RISK}

Assessment of probable loss due to a natural hazard scenario. In this example, average annual loss as a percentage of the asset value by local-level

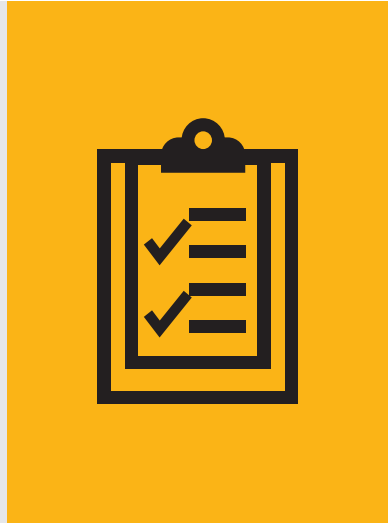

Source: : Adapted from Pacific Catastrophe Risk Financing and Insurance Initiative. 2011. Country Risk Profile: Papua New Guinea. Washington, DC. The Pacific Catastrophe Risk Financing and Insurance Initiative is a collaboration between the Secretariat of the Pacific Community, ADB, the Government of Japan, and the World Bank. 
Disaster risk modelers apply the above function to the challenging task of bringing together disparate datasets that describe natural and human phenomena into a framework that helps guide development and planning decisions related to disaster and climate risk. Disaster risk assessment is inherently an information-intensive process, and obtaining the necessary input data required to develop the models can be one of the more time-consuming and difficult parts of the process. This guide addresses data related to the natural hazard element of the disaster risk function. The companion document, Disaster Risk Assessment for Project Preparation: A Practical Guide, discusses other elements of the process.

\section{B. Measuring Natural Hazard: Frequency, Intensity, Location}

For the purposes of disaster risk assessment, the concept of a natural hazard is understood to have three interrelated characteristics: intensity, frequency, and location.

- Intensity is the observed or potential severity of a given natural hazard; for example, the wind speed of a tropical cyclone ${ }^{6}$ or the shaking of an earthquake.

- Frequency is related to how often a natural hazard of a particular intensity is likely to occur or has occurred in a given location.

- Location is the affected geographical area. Natural hazards are inherently spatial phenomena.

Due to the spatial character of natural hazards, maps are commonly used to provide visual depictions of hazard information. For example, Figure 2 presents maps of tsunami and flood hazards, indicating their intensity and location. Specialized geographic information system (GIS) software that can accommodate spatial data is commonly required for creating, managing, and visualizing hazard data. ${ }^{7}$ Remote-sensing technologies are also critical, as discussed in Box 1.

Figure 2: Natural Hazard Maps

\section{A. Tsunami hazard near Maumere, Indonesia}

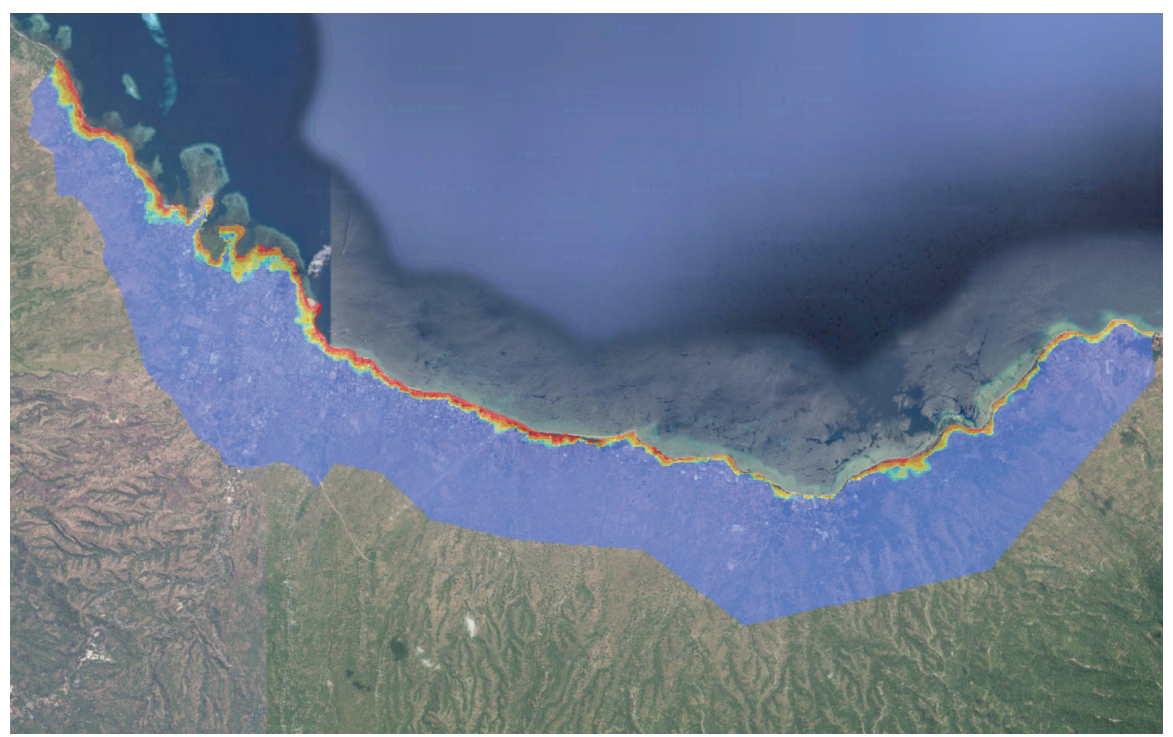

Note: Coastal tsunami hazard, modeled based on 8.1 moment magnitude earthquake near Maumere, Indonesia. The darker color indicates greater water depth.

Source: Government of Australia and Badan Geologi. Creative Commons Licensed. http://docs.inasafe.org/en/training/socialisation/datasets.html

The United States National Oceanic and Atmospheric Administration (NOAA) defines tropical cyclones as "a rotating, organized system of cloudsand thunderstorms that originates over tropical or subtropical waters." In some parts of the world, they are also referred to as hurricanes or typhoons. For consistency, this document will use the term tropical cyclone. For more information, see http://www.nhc.noaa.gov/climo

7 GIS software includes excellent, free, and open source options such as GQIS (http://qgis.org/en/site/), as well as paid software such as ArcGIS (https://www.arcgis.com). 


\section{B. Flood hazard in Jakarta}

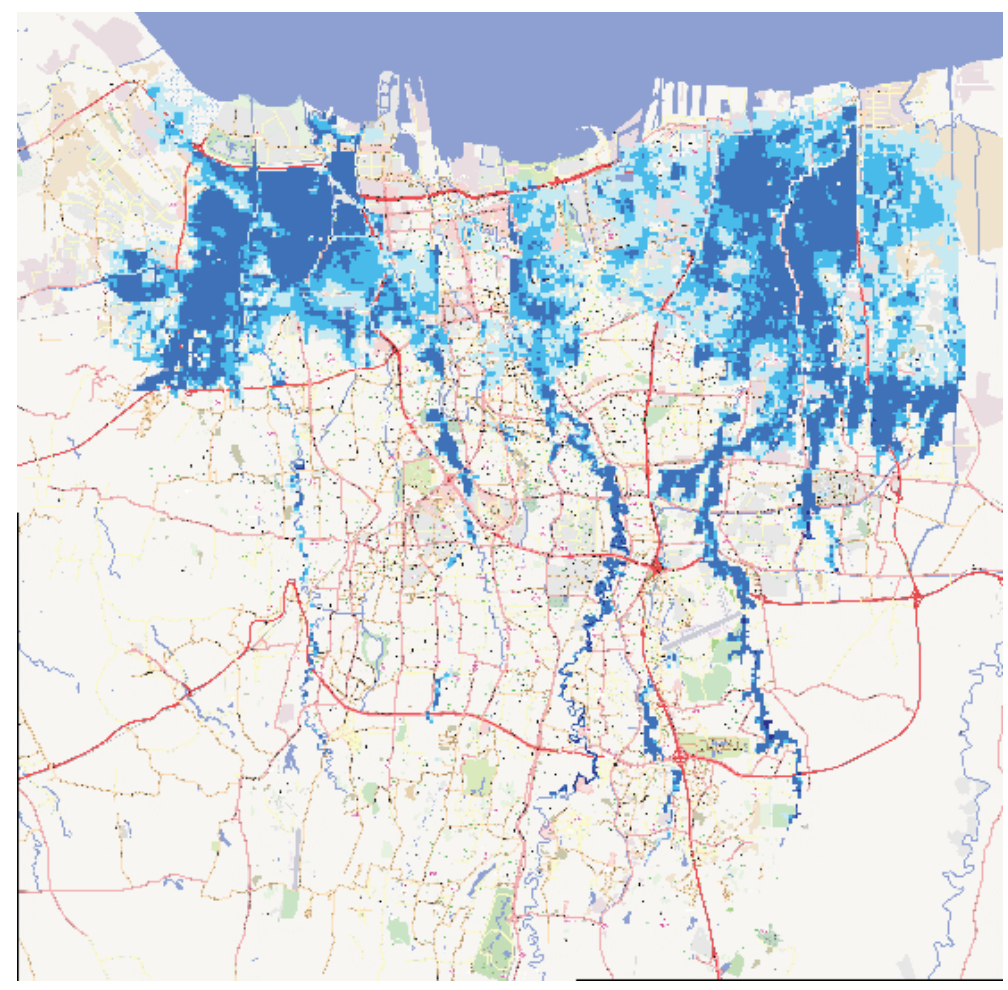

http://docs.inasafe.org/en/training/socialisation/datasets.html
Note: Based on flood conditions experienced in 2007 (section 2.D on the role of historical records). The darker color indicates greater water depth.

Sources: Deltares and City of Jakarta. Creative Commons Licensed.

\section{Box 1: Remote Sensing and Natural Hazard Assessment}

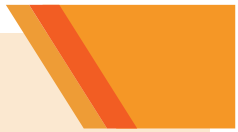

Natural hazards are an inherently spatial concept. A key component of natural hazard assessment relates to developing an understanding of how hazards vary across space. As a result, the majority of natural hazard data is captured in spatial formats. Remote-sensing technologies and geographic information systems are critical tools for creating, analyzing, and communicating spatial information about natural hazards.

Remote-sensing data, often in the form of information captured through camera or radar technology aboard satellites or airplanes, are an important part of applications related to understanding numerous natural and social phenomena. ${ }^{a}$ They play a role in assessing natural hazards as well. For example, radar technology is widely used to create elevation data, a necessary component of flood and landslide modeling; for instance, the digital elevation model underlying the flood model of the Global Assessment Report on Disaster Risk Reduction 2015. Satellite imagery can also be used to model patterns of land cover and land use or to capture characteristics of disaster events, such as flood extent, for use in future natural hazard assessment.

a See Satellites in Global Development. http://satsummit.github.io/landscape Source: ADB. 


\section{Understanding Return Periods}

The return period is an important concept when working with natural hazard information. It can appear as both a unit of analysis and a descriptor. For instance, hazard data for earthquakes labeled eq_500yr in the 2015 Global Assessment Report on Disaster Risk Reduction (GAR), ${ }^{8}$ published by the United Nations Office for Disaster Risk Reduction (UNISDR), describe the maximum probable earthquake intensity in a 500year period for every location for which the dataset has coverage. In this case, the return period refers to the unit of analysis. The GAR initiative is explained in further detail in Box 2.9

The second way in which the idea of return periods is used is to describe individual historical or potential natural hazard events. For example, a 100-year or a 1-in-100-year flood refers to a flood of an intensity that has a $1 \%$ likelihood of occurring in any given year. However, it is frequently understood to mean a flood of an intensity that is likely to occur every 100 years. This confusion is somewhat problematic and can lead to misinterpretation, especially by the general public. It is equally possible to have two successive 100-year floods within 2 succeeding years, within 20 years of each other, or 150 or more years apart. Over the very long term, however, they will occur once every 100 years on average and, hence, have a $1 \%$ probability of occurring in a given year.

\section{Box 2: Global Assessment Report on Disaster Risk Reducation}

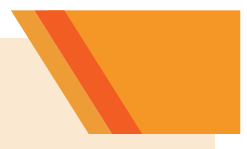

Every 2 years, the United Nations Office for Disaster Risk Reduction (UNISDR) publishes a major report compiling a review and analysis of data and information on disaster risk patterns and trends, government self-assessments of progress, and an analysis of critical challenges to disaster risk reduction. The Global Assessment Report on Disaster Risk Reduction (GAR) provides global datasets describing natural hazard, exposure, and risk for many weather and geophysical hazards. Results of the GAR hazard assessment are intended to provide the foundation for global and regional comparison. They are typically too coarse to use in local planning purposes.

Maps and data from the most recent 2015 report can be accessed at http://risk.preventionweb. net/capraviewer/download.jsp

An overview report of the data and methods included can be found at http://www.preventionweb.net/english/hyogo/gar/2015/en/gar-pdf/Annex1-GAR_Global_Risk_ Assessment_Data_methodology_and_usage.pdf

The 2015 GAR makes its data and maps available free for use in scientific and not-for-profit purposes, with a request for attribution if incorporated in a publication. ${ }^{a}$

a See http://risk.preventionweb.net/capraviewer/download.jsp?tab=11

Source: UNISDR. Global Assessment Report. https://www.unisdr.org/we/inform/gar

UNISDR. 2015. Global Assessment Report on Disaster Risk Reduction 2015-Making Development Sustainable: The Future of Disaster Risk Management. Geneva.

9 Discussion of individual GAR datasets, as relevant, is in section 4. 


\section{The Role of Historical Catalogs}

Records of past natural hazard events play an important role in developing the understanding of present and future hazard potential where available. Such records typically include a measure of natural hazard intensity and location, as well as dates of occurrence. In some cases, these catalogs can stretch back hundreds of years, with researchers working through historical documents to estimate the characteristics of more distant events. More commonly, however, records go back only a few decades. Entries for recent events are often based on precise observation and measurement.

Historical records, while often not complete or reliable, can be useful in the absence of other data or as inputs to more robust natural hazard assessments (section 3). They help gauge return periods of recurring events, calibrate models, and identify geographic areas of particular concern. Historical catalogs that cover longer time periods, where reliable and where they exist, are preferable. Historical records for relatively limited periods of time tend to underreport lower-frequency, higher-impact events. For example, the volcano hazards dataset in the 2015 GAR was based on observed eruptions over a period of just 3 decades. Each volcano was classified as being high, medium, or low hazard, based on the frequency of eruptions over this period. While this approach is common and useful, the results are more robust for higher-frequency events. Attempts at understanding lower-frequency, higher-impact events such as volcanic eruptions require longer historical records or models that take into account climatic and geophysical characteristics of the particular location being studied.

\section{E. Probabilistic and Deterministic Approaches to Natural Hazards}

There are two approaches for understanding and measuring natural hazards: deterministic and probabilistic.

Deterministic hazard analysis is based on a scenario or event. For example, a deterministic hazard model may show the extent or depth of flooding that would result from a particular rainfall event or the amount of ground-shaking that would occur due to a given magnitude earthquake at a specific location along a fault. For a particular source event, a deterministic approach seeks to convey the geographic extent and intensity of the natural hazard for the area of concern. Deterministic scenarios are usually used for slowonset hazards such as drought.

Probabilistic hazard analysis relies on many, sometimes thousands of, possible source events to assess the probability of a certain intensity of natural hazard at a given location. This approach is increasingly possible as modeling techniques have improved, and it is growing particularly common in seismic hazard and tropical cyclone modeling. Outputs can be expressed in the form of a hazard map, as illustrated in the case of seismic hazards in Papua New Guinea in Figure 3, among other ways. 
Figure 3: Probabilistic Seismic Hazard Map of Papua New Guinea: Peak Ground Acceleration

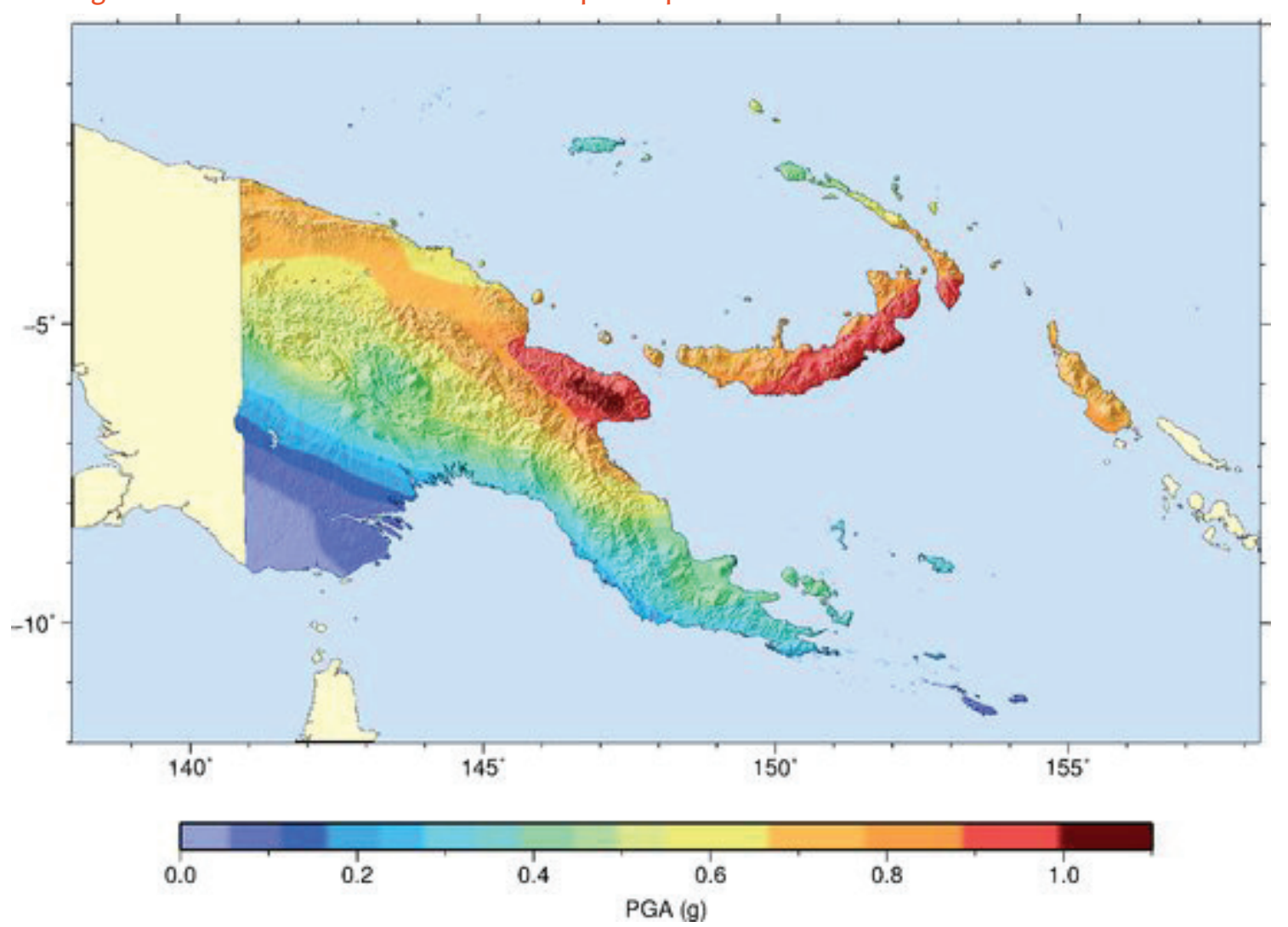

Source: GEM Foundation. 2015. https://www.globalquakemodel.org/get-involved/news/openquake/png-clears-ground-newbuilding-codes/

\section{F. Climate Change and Natural Hazards}

Natural hazards fall into two categories, reflecting their underlying natural causes: (i) geophysical hazards, such as earthquakes, tsunamis, and volcanic eruptions; and (ii) hydrometeorological hazards or extreme weather events, such as floods, drought, and tropical cyclones. Climate change is expected to impact extreme weather events in complex and significant ways. Although the unequivocal causal link between climate change and change in patterns of extreme weather events is yet to be established, there is a meaningful consensus that the increased energy in the global climate system caused by enhanced greenhouse gas effects will have an impact on weather variability. According to the Fifth Assessment Report of the Intergovernmental Panel on Climate Change (IPCC), ${ }^{10}$ Asia is anticipated to experience more frequent and intense heat waves and an increase in heavy rain events, both during monsoons and near the center of tropical cyclones making landfall, along with widespread issues related to water shortage. The IPCC expects major effects of climate change on Pacific island countries to include sea-level rise, increased intensity and frequency of tropical cyclones, and more frequent extreme rainfall events.

10 IPCC. 2013. Climate Change 2013: The Physical Science Basis. Contribution of Working Group I to the Fifth Assessment Report of the Intergovernmental Panel on Climate Change. T.F. Stocker, D. Qin, G.-K. Plattner, M. Tignor, S.K. Allen, J. Boschung, A. Nauels, Y. Xia, V. Bex and P.M. Midgley (eds.). Cambridge, UK and New York, NY: Cambridge University Press. 
Therefore, any efforts to create or understand information about future weather-related hazards must consider the projected impacts of climate change-and, in particular, the expected increased variability in weather patternsin the geographic area under consideration. The IPCC special report Managing the Risks of Extreme Events and Disasters to Advance Climate Change Adaptation (SREX) ${ }^{11}$ provides a comprehensive assessment of the scientific literature on issues related to, among others, the relationship between climate change and extreme weather and climate events (climate extremes).

To date, global climate models (GCMs), also known as general circulation models, have been used to provide internally consistent projections of climate change. Downscaling of these model outputs, either statistically or dynamically, is needed to derive climate change projections suitable for (often local-level) natural hazard risk analyses. Efforts are being made, including by ADB and its partners, to coordinate the downscaling of GCM outputs to facilitate climate risk analyses at regional and local scales. The IPCC's data distribution center provides details on the availability of GCM outputs and associated guidance documents on downscaling and the use of direct GCM outputs, as well as downscaled data products for climate impact and risk assessments. ${ }^{12}$

11 IPCC. 2012. Managing the Risks of Extreme Events and Disasters to Advance Climate Change Adaptation: A Special Report of Working Groups I and Il of the Intergovernmental Panel on Climate Change. C.B. Field, V. Barros, T.F. Stocker, D. Qin, D.J. Dokken, K.L. Ebi, M.D. Mastrandrea, K.J. Mach, G.-K. Plattner, S.K. Allen, M. Tignor, and P.M. Midgley (eds.). Cambridge, UK and New York, NY: Cambridge University Press. http:// www.ipcc.ch/report/srex

12 See Intergovernmental Panel on Climate Change. http://www.ipcc-data.org 


\section{Factors to Consider in Assessing Natural Hazard Datasets for Operational Purposes}

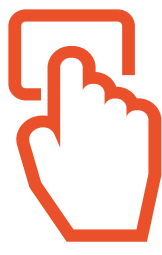

\section{A. Introduction}

In some cases, there may be many natural hazard datasets to choose from for project disaster risk screening and design purposes, and to inform the preparation of country partnership strategies. In others, new data may need to be developed. In general, consultants or firms with appropriate technical expertise should be able to provide technical guidance. It is important, however, for project officers to understand the basics of assessing available data to best guide and interact with technical experts. This section addresses some of the key issues for consideration in identifying and, where necessary, commissioning the preparation of appropriate natural hazard datasets.

\section{B. Scale and Resolution}

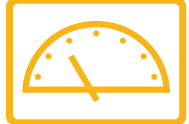

When assessing natural hazard data, one of the most important factors to consider is the level of detail at which spatial data attempt to represent the world. There are two common means by which this concept is typically measured: scale and resolution.

Scale is the relationship or ratio between the size of features as depicted on a map and their actual size. It is usually expressed in two numbers separated by a colon, where the unit to the left of the colon is the distance on the map, and the unit on the right is the corresponding distance on the ground. For example, 1:100,000 means that 1 unit on the map represents 100,000 of the same unit on the ground. So, if the unit is centimeter $(\mathrm{cm})$, then $1 \mathrm{~cm}$ on the map represents $100,000 \mathrm{~cm}$ (1 kilometer [km]) on the ground. Larger-scale maps convey greater detail than smaller-scale maps.

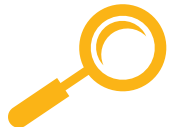

Resolution is more commonly encountered when dealing with digitized natural hazard data. It is the corresponding size of one pixel in the grid to the amount of area in the world that the information contained in that pixel represents. For example, a 90-meter $(\mathrm{m})$ resolution digital elevation model (DEM) from the Shuttle Radar Topography Mission (section 5) represents the mean elevation for each $90 \mathrm{~m} \times 90 \mathrm{~m}$ cell in the area covered by the dataset. Figure 4 illustrates a DEM, in this case prepared to a resolution of $30 \mathrm{~m}$. 


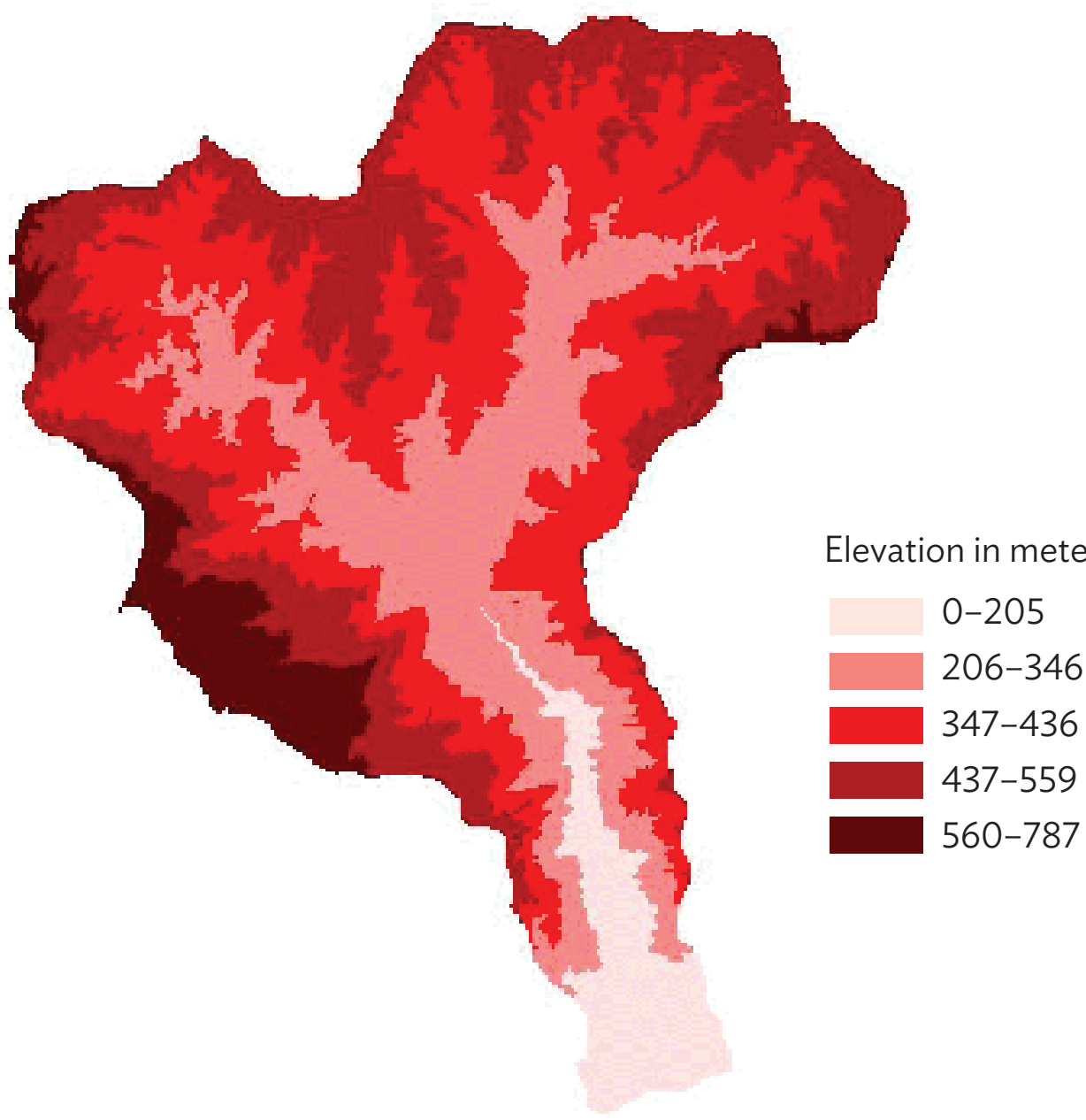

Source: Used with permission from GIS Lounge.

https://www.gislounge.com/geodatabases-explored-vector-and-raster-data/

Typically, higher-resolution or -scale data are understood to provide more detail. Sometimes this level of detail is unnecessary. Users should consider for what purpose data will be used and what decisions will be made based on that information. For regional-scale planning or for identifying first-order priorities, 100 $\mathrm{km}$ or $500 \mathrm{~km}$ resolution data may be sufficient. For planning related to very local landslides or to flood risk management interventions, even $30 \mathrm{~m}$ resolution data may need to be supplemented with detailed site surveys.

\section{Temporality}

It is important to be aware of the date of the creation of a dataset. This is particularly vital for data pertaining to frequently changing phenomena, such as dynamic river systems or terrain morphology. In general, working with newer natural hazard datasets is preferable, but this is heavily context dependent and there are many other factors to be considered, including methodological robustness. Newer datasets can, although not always, reflect improvements in modeling techniques or incorporation of improved input datasets. Technology advances, such as increased sensitivity of instrumentation, are another reason why it can be desirable to work with more recent datasets. 
When considering historic disaster records, it is also important to assess the return period of each event over the recorded period. In general, historical records tend to underreport lower-frequency, higher-impact events (section 2.D). A 30-year flood record, for example, will likely not include large flood events with 100- or 500-year return periods. Historic catalogs that cover longer time periods, where reliable and where they exist, are therefore preferable.

\section{Data Gaps}

1" There are significant data challenges in many developing member countries (DMCs) relating to gaps in historical data. Rainfall records are often incomplete, for instance, and networks of reading stations sometimes too sparse. River system data for tributaries and more minor rivers are virtually nonexistent in some countries. Technical expertise should be sought regarding interpolation methods to estimate missing data points, taking into account context-specific factors such as the type of data, domain, extent of gaps, and desired confidence level (reliability) of the analysis.

\section{E. Authoritativeness}

The authoritativeness of a particular dataset stems from the individual, organization, or institution that created, maintains, or is otherwise associated with it. There are two important sources of authority worthy of consideration when assessing the suitability of available natural hazard information. The first is mandated authority. Many government ministries have a legal responsibility to create and manage official datasets. For example, meteorological agencies in many countries are responsible for producing precipitation records. The second relates to the reputation for scientific or technical expertise held by the individual or organizations responsible for creating the data. It is not necessarily the case that authoritative datasets will be of the highest quality nor that mandated responsibilities will be met in full. However, authority can help increase trust in the data and the results of any modeling or analysis based on them.

\section{F. Licensing and Open Data}

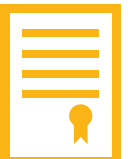

One often overlooked challenge in working with natural hazard data relates to restrictions on access, use, and redistribution of datasets and risk assessments. The license, or terms of use, under which datasets are released, has a significant but little understood impact on whether particular data can be used. There are many components to a well-written data license; the most important relate to attribution, modification, and redistribution. Attribution refers to giving credit to the owner or creator of the data in any publications. Modification refers to guidance on how users seeking to edit a dataset or combine it with others should document and share their results. Redistribution clauses of a data license describe permissions regarding further sharing of the dataset or derived products and their use in commercial endeavors.

A common challenge is that data providers, including within government, may charge other users-even other government agencies-for access to information as part of an effort to recover the costs associated with the creation or maintenance of the dataset. Such costs are often due to systemic underfunding of data collection activities in many countries. Open data advocates suggest that spatial data should be recognized as a public good and that data, maintained and created by governments, should be released under permissive, open licenses that encourage use and redistribution, as occurs, for instance, in the United Kingdom (Box 3). The International Charter 'Space and Major Disasters' and the Sentinel Asia initiative provide further examples of data sharing, in these cases in the context of disaster response (Box 4). 


\section{Box 3: United Kingdom Open Data Policy}

The Government of the United Kingdom has been working on an ambitious open data strategy for over a decade. The policy consists of:

- an open data portal (http://data.gov.uk) launched in 2009 where the public can access open government data; ${ }^{a}$

- a series of government mandates and legislative acts describing how data should be released; and

- a number of resources, including a standard open government license, aimed at helping government agencies and the public make the most of open data. ${ }^{2}$

Since 2009, the data.gov.uk website has released over 30,000 datasets, including public servant salaries, public expenditures, government contracts, spatial data, and meteorological data. This has resulted in creative and valuable uses of this information in applications and research, spanning from transportation to disaster preparedness, as well as public contribution to the improvement of government datasets. The United Kingdom's open data policy has benefited from high-level government support from the outset. In 2009, for example, Prime Minister Gordon Brown stated that "public information does not belong to government, it belongs to the public."'

More resources describing open data efforts in the United Kingdom can be found at https://www. gov.uk/service-manual/technology/open-data.html

a See http://www.nationalarchives.gov.uk/doc/open-government-licence/version/3/

b Quoted from D. Wood, ed. 2011. Linking Government Data. Springer Science \& Business Media.

Source: ADB.

\section{Box 4: International Charter 'Space and Major Disasters' and Sentinel Asia}

The International Charter 'Space and Major Disasters' and Sentinel Asia focus on the provision of hazard-related spatial data in the context of major disasters to help inform emergency response. The charter was initiated by the European and French space agencies in 1999. A further 11 agencies have subsequently joined the charter, including the Chinese, Japanese, and Korean space agencies. Sentinel Asia is a regional initiative for the same purpose, promoting international cooperation on natural hazard monitoring in the Asia and Pacific region. It uses earth observation satellites and other space technologies to collect disaster-related information, and shares it over the internet. Sentinel Asia was established in 2005, with membership reaching 8 international organizations and 51 participating organizations from 20 countries by 2016, including the Asian Development Bank.

Sources: International Charter: Space and Major Disasters. https://www.disasterscharter.org/; Sentinel Asia. https://sentinel.tksc.jaxa.jp/sentinel2/MB_HTML/About/About.htm 


\section{G. Data Formats}

The data or file format in which a dataset is stored can affect the ease with which it can be used in another project. In recent years, this has become much less of a problem, but in the past a dataset created in one software tool could not be used or manipulated by another. Standard data formats, such as those promoted by the Open Geospatial Consortium, ${ }^{13}$ are increasingly common and have helped alleviate incompatibility challenges. Data formats can typically be identified by their file extension, such as .xls and .csv for tabular data and .shp, geojson, and .kml for spatial data. When selecting datasets or funding the creation of new data, it is worth ensuring that standard formats are used, although experienced experts will likely do this as a matter of practice.

13 See Open Geospatial Consortium. http://www.opengeospatial.org/ 


\section{Discussions of Natural Hazard Data by Type}

\section{A. Geophysical}

\section{Earthquake}

Measuring earthquake hazard. Scientists use a variety of measures to describe the relative size of earthquakes. This includes magnitude, which is the amount of energy released as the result of seismic activity at the source, and intensity, which is the site-specific amount of shaking experienced across the affected area. ${ }^{14}$ For purposes of hazard assessment, an earthquake is frequently described in terms of peak ground acceleration (PGA). Ground acceleration, in seismological terms, is the increase in speed of motion of the earth during a seismic event. PGA for hazard modeling is, therefore, the maximum predicted acceleration at a specific site for a given event or return period. An earthquake hazard map showing PGA for a 475-year event for a segment of Asia is shown in Figure 5.

Figure 5: Global Earthquake Hazard Map for a 475-Year Event (in PGA [cm/s2])

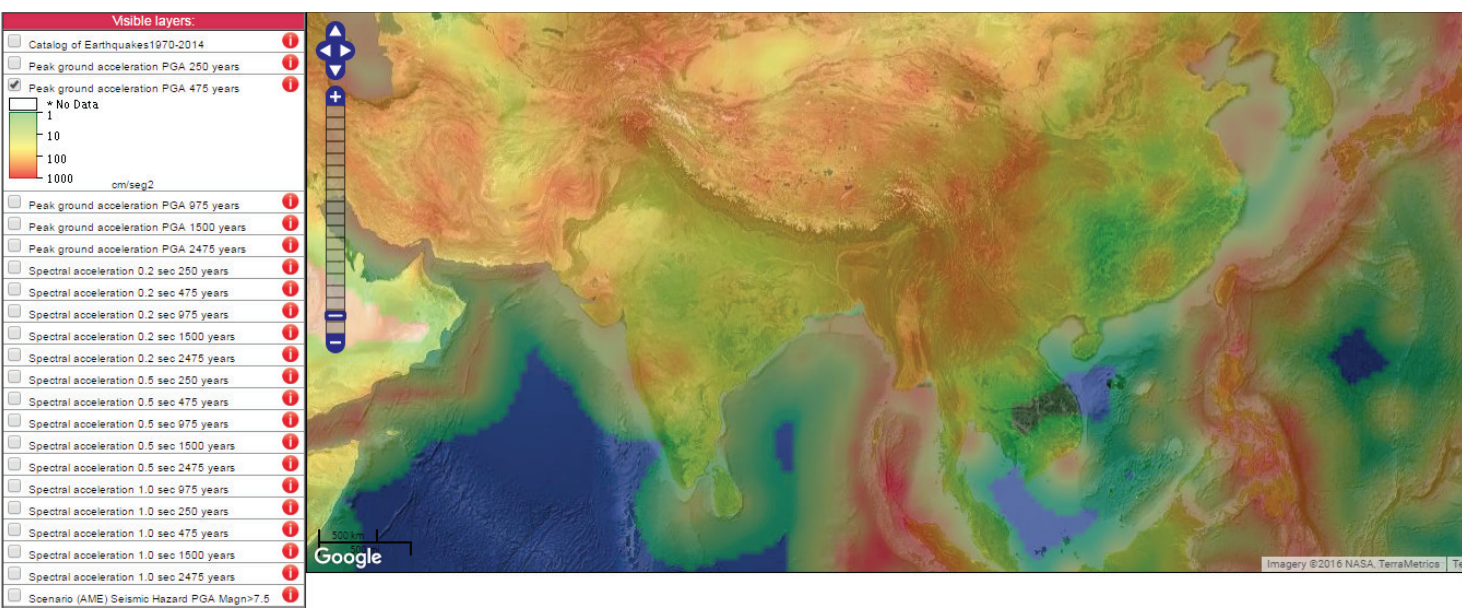

Source: Comprehensive Approach to Probabilistic Risk Assessment (Probabilistic Risk Assessment) Program. http://risk. preventionweb.net/capraviewer/main.jsp?tab=2\&mapcenter=0,2965169.792775\&mapzoom=1 (accessed 9 September 2016).

The seismicity of a region, country, or location is assessed using the available historical record, data about the location and characteristics of active faults, data from GPS networks that monitor fault movements, and data from networks of seismic stations that record ongoing ground motion activity, even if it is not felt. This information is combined to model earthquake sources and their frequency of earthquake-triggering ruptures. To develop a measure of potential or probable PGA, source information is complemented with other types of geologic data, including distance from rupture, soil type, depth and characteristics of bedrock, and topography. These variables determine potential acceleration at given locations. The resolution of seismic hazard maps is frequently limited by the resolution of these secondary datasets. Meanwhile, their reliability can be affected by incomplete seismic history, inadequate seismograph records, or limited exploratory analysis. For instance, a 2016 study of Bangladesh, India, and Myanmar has found new evidence that the northeastern corner of the Indian subcontinent is actively colliding with Asia, potentially posing previously

14 Detailed information about the measurement of seismic activity can be found at the United States Geological Survey. http://www. usgs.gov/faq/taxonomy/term/9828 14 and http://earthquake.usgs.gov/learn/glossary/?term=acceleration 
unrecognized major risk to the region with earthquakes of up to magnitude $9 .{ }^{15} \mathrm{As}$ with all data discussed in this report, understanding the limitations of seismic hazard models and how they were produced is key to their responsible use.

Global data sources and resources. The 2015 GAR's linked risk data platform provides maximum probable PGA data, measured in $\mathrm{cm} / \mathrm{s}^{2}$, for earthquakes with return periods of $250,475,975,1,500$, and 2,475 years. ${ }^{16}$ The background paper for the probabilistic seismic hazard assessment ${ }^{17}$ reports a spatial resolution of 0.3 degrees, or about 33 square kilometers $\left(\mathrm{km}^{2}\right)$. However, the data available for download are in 50 $\mathrm{km}^{2}$ grid format. These data were developed using the CAPRA (Probabilistic Risk Assessment) software. ${ }^{18}$

The Global Earthquake Model (GEM) aims to provide a consistent, global suite of open source tools, data, and models for estimating seismic risk. This includes a global catalog of nearly 1,000 seismic events of over 5.5 magnitude between 1900 and 2009 and source data from nearly 150 countries. Coverage is on a per country basis, but there is a significant amount of data available for the Asia and Pacific region. Much of the GEM data can be accessed in raw formats by downloading the OpenQuake software. ${ }^{19}$ The OpenQuake suite of tools is an open source software for creating and sharing earthquake hazard data. Typically, GEM datasets are combined with local data, as available, for estimation of hazard. More information about GEM and how to use it can be found at http://www.globalquakemodel.org/openquake/about/

National data sources. Many countries have specific agencies with responsibility for maintaining networks of seismographs, historical catalogs of earthquake activity, and other source information. Often, these agencies are associated with the government entity responsible for geologic research and information. For example, the Government of Nepal hosts a National Seismological Centre within the Department of Mines and Geology. ${ }^{20}$ The National Seismological Centre oversees the country's network of seismic monitoring stations, produces a national seismic hazard map in both print and digital formats, and maintains a historic earthquake activity catalog containing the time and date, latitude-longitude coordinates, and the magnitude of the shaking for each earthquake event. Other common national data sources include topographic data, which are frequently maintained by a country's national mapping agency, and soil maps, which are usually created and maintained by a country's agricultural agency.

\section{Tsunami}

Measuring tsunami hazard. Tsunamis are waves caused by the displacement of a large volume of water as a consequence of geophysical activity in or near large bodies of water. Around $80 \%$ of tsunamis are caused by coastal or underwater earthquakes, and this figure is even higher in the case of major tsunamis. Tsunamis can also be triggered by landslides and volcanic eruptions, both above land and under water.

Tsunami hazard can be measured as the extent or the depth of water run-up (i.e., the extent of inundation of seawater on land). Flow direction and velocity are sometimes modeled as well. The hazard can be assessed deterministically as the result of a particular geologic event, or probabilistically as the likelihood of a given intensity over a given return period. In some cases, tsunami hazard is modeled as an index based on probability of occurrence and potential impact. Tsunami hazard is estimated using the source of water

15 M.S. Steckler, D.R. Mondal, S.H. Akhter, L Seeber, L. Feng, J. Gale, E.M. Hill, and M. Howe. 2016. Locked and Loading Megathrust Linked to Active Subduction beneath the Indo-Burman Ranges. Nature Geoscience. 9(8). pp. 615-618.

16 See Global Assessment Report on Disaster Risk Reduction Risk Data Platform. http://risk.preventionweb.net/

17 Global Facility for Disaster Reduction and Recovery. 2014. Understanding Risk: The Evolution of Disaster Risk Assessment since 2005. Background paper prepared for the 2015 Global Assessment Report on Disaster Risk Reduction. http://www.preventionweb.net/ english/hyogo/gar/2015/en/bgdocs/CIMNE-INGENIAR,\%202014a.pdf

18 The CAPRA Program seeks to increase partner countries' ability to conduct and utilize risk assessment through capacity development and the distribution of open source software. More information can be found at https://ecapra.uniandes.edu.co/

19 The software is available at OpenQuake. https://platform.openquake.org/

20 See Government of Nepal's National Seismological Centre. http://www.seismonepal.gov.np 
displacement based on seismographic, landslide, or volcanic models and coastline information to predict run-up. Run-up or flooding models also rely on bathymetry (seafloor topography), coastal elevation, and land-use or-cover data.

Global data sources. The 2015 GAR includes a dataset describing the maximum probable run-up for a 500-year return period. It is available for download from the GAR data download page. These data were created by the Norwegian Geotechnical Institute. The authors of the background documentation list several limitations of this dataset. ${ }^{21}$ First, the model only considers tsunamis generated by large earthquakes exceeding 7.85 magnitude. Second, the precise return periods of large earthquakes are difficult to estimate with precision because of the lack of historical record. Third, run-up is calculated using coarse elevation data and may underrepresent tsunami hazard in some areas.

The United States National Oceanic and Atmospheric Administration (NOAA) maintains a freely accessible historical catalog of global tsunami data. ${ }^{22}$ The NOAA historical catalog contains both source and run-up information for over 2,500 events between $2000 \mathrm{BC}$ and the present. Event data cover source location, date and time, source event magnitude, maximum water height, total number of deaths and injuries, and damages for the source event. Run-up data cover arrival date and time, travel time, maximum water height, horizontal inundation distance, deaths, injuries, and damage for specific locations. NOAA's National Weather Service also maintains a website for the Pacific Tsunami Warning Center. ${ }^{23}$

Regional and national data sources. Disaster response or coastal management agencies maintain tsunami early warning systems. Source data can often be obtained from national agencies working on earthquake, landslide, or volcano hazard. Land cover, bathymetric, and topographic data are frequently maintained by a country's national mapping agency.

The Indian Ocean Tsunami Information Center was created in 2005, following the December 2004 Indian Ocean tsunami, to provide hazard information, resources, and early warnings to countries in the Indian Ocean basin. In addition to supporting a network of national tsunami early warning centers, ${ }^{24}$ the organization has conducted tsunami hazard assessments for the region and provides training to national governments.

\section{Volcano}

Measuring volcano hazard. There are multiple hazards associated with volcanic eruption. These include lava flow and ash fall. Volcanoes can often lie dormant for many years before becoming active. Due to the long return period and poor historical record of eruptions, the creation of a reliable hazard assessment for volcanoes is quite difficult. As a result, most volcano hazard datasets, especially those produced at regional and global scales, are indexes, based on observed activity, rather than modeled hazard.

Global data sources. The Global Volcano Model Network is a consortium of scientists and research institutions that has developed a volcano hazard index ( $\mathrm{VHI})$. The $\mathrm{VHI}$ is a composite indicator built using historical eruption frequency and occurrence of pyroclastic, mud, and lava flows based on the Volcanoes

${ }_{21}$ Norwegian Geotechnical Institute and Geoscience Australia. 2014. Tsunami Methodology and Result Overview. Report prepared for the UNISDR Global Assessment Report 2015 - GAR15. http://www.preventionweb.net/english/hyogo/gar/2015/en/bgdocs/ risk-section/Norwegian\%20Geolotechnical\%20Institute\%20(NGI)\%20and\%20\%20Geoscience\%20Australia\%20(GA),\%20 Tsunami\%20Methodology\%20and\%20 Result\%200verview.pdf

22 See United States National Oceanic and Atmospheric Administration. https://www.ngdc.noaa.gov/hazard/tsu_db.shtml

23 See Pacific Tsunami Warning Center. http://ptwc.weather.gov/

24 See Indian Ocean Tsunami Information Center. http://iotic.ioc-unesco.org/indian-ocean-tsunami-warning-system/tsunami-early-warning-centres/56/national-tsunamiwarning-Centres 
of the World (VOTW 4.0) database. ${ }^{25}$ The index ranks countries on a scale from 1 to 3 and from low to high hazard, and it is designed to estimate the level of threat over the next 30 years. The VHI is available from the GAR data download site as a vector point file. ${ }^{26}$ This work builds upon prior methodologies, but should be used with caution. Due to the long return period of many volcanoes, only 328 (about 20\%) of the 1,546 of volcanoes in the Volcanoes of the World database (covering most known volcanoes in the world) have sufficient information ( 4 or more recorded events) to assign a score according to the $\mathrm{VHI}$ methodology. ${ }^{27} \mathrm{The} \mathrm{VHI}$, therefore, should be used only after full consideration of its limitations and with proper disclosure to end-users.

National data sources. At the national level, geological or disaster management agencies will typically be responsible for studying and monitoring volcanic hazards, managing early warning systems, and maintaining maps and other information.

\section{B. Weather}

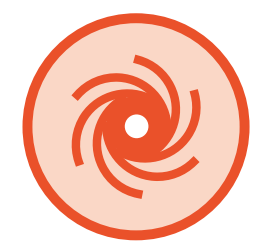

\section{Tropical Cyclone}

Measuring cyclone hazard. Tropical cyclones typically present three kinds of hazard, each of which can be modeled separately: wind, rainfall, and coastal storm surge. Storm surges are often the deadliest, although precipitation can cause inland flooding or induce landslides with severe impacts. Storm surge is usually measured as run-up distance; wind as wind speed, often the maximum speed sustained for a period of three seconds or more; and precipitation as millimeters of rainfall or depth of inundation. There are various scales of measurement of their intensity, as described in Box 5 . The maximum potential storm surge for a particular location depends on various factors, including storm intensity and characteristics (speed, size, and angle of approach), and the shape and characteristics of the coast, including the slope of the shore. ${ }^{28}$

Bathymetry and elevation are, thus, important for understanding storm surge potential. Elevation, land use, soil, and riverine network data can be used to assess other secondary tropical cyclone hazards, such as landslide or inland flooding associated with precipitation. Historical cyclone tracks are commonly used to assess overall wind hazard. Hazard analyses that rely upon such tracks are increasingly robust with regard to wind speed and storm surge, but less so for resulting flooding. Historical data can also be combined with knowledge on the physical nature of an event to produce simulations of potential future events. Simulated tropical cyclone tracks for Viet Nam and the Philippines are illustrated in Figure 6.

Global hazard data. The 2013 GAR provides a global tropical cyclone hazard dataset. ${ }^{29}$ It classifies $1 \mathrm{~km}$ grid cells that experienced at least one category 1 or greater cyclone between 1968 and 2009 as being in a hazard area for tropical cyclones. Cyclone tracks are taken from the International Best Track Archive for Climate Stewardship (IBTrACS) maintained by NOAA.

For each event, IBTrACS data ${ }^{30}$ for global tropical cyclones cover record date (hour, day, month, year), central pressure of the cyclone (in millibars), geographical positioning (latitude, longitude), maximum

25 See Volcanoes of the World (VOTW 4.0) database. http://volcano.si.edu/gvp_votw.cfm

26 See Global Assessment Report on Disaster Risk Reduction Risk Data Platform. http://risk.preventionweb.net/capraviewer/main jsp?countrycode $=$ g15

27 S.K. Brown, S.C. Loughlin, R.S.J. Sparks, and C. Vye-Brown. 2015. Global Volcanic Hazards ad Risk. Technical background paper for the UN-ISDR Global Assessment Report on Disaster Risk Reduction 2015. A report by Global Volcano Model and the International Association of Volcanology and Chemistry of the Earth's Interior. http://www.preventionweb.net/english/hyogo/ gar/2015/en/bgdocs/GVM,\%202014b.pdf

28 UNISDR. 2015. Making Development Sustainable: The Future of Disaster Risk Management. Global Assessment Report on Disaster Risk Reduction. Geneva (Appendix 1: Data, Methodology, Sources, and Usage, page 15). http://www.preventionweb.net/english/ hyogo/gar/2015/en/gar-pdf/Annex1-GAR_Global_Risk_Assessment_Data_methodology_and_usage.pdf

29 See Global Risk Data Platform. http://preview.grid.unep.ch/index.php?preview=data\&events=cyclones\&evcat=7\&lang=eng

30 See United States National Oceanic and Atmospheric Administration. https://www.ncdc.noaa.gov/ibtracs/index.php?name=ibtracs-data-access 
Tropical cyclones are monitored and classified by different national and international agencies around the world, depending on the region in which they occur. Most scales rely on wind speed, either maximum or sustained gust, to categorize the severity of a cyclone. Two of the most commonly used scales, the Saffir-Simpson hurricane wind scale and the Australian tropical cyclone intensity scale, are compared below.

\begin{tabular}{ccc|}
\hline Category & Saffir-Simpson Wind Scale & $\begin{array}{c}\text { Australian Tropical Cyclone } \\
\text { Intensity Scale }\end{array}$ \\
\hline One & $74-95 \mathrm{mph}$ & $63-88 \mathrm{kmh}$ \\
Two & $96-110 \mathrm{mph}$ & $89-117 \mathrm{kmh}$ \\
Three & $111-129 \mathrm{mph}$ & $118-169 \mathrm{kmh}$ \\
Four & $130-156 \mathrm{mph}$ & $160-200 \mathrm{kmh}$ \\
Five & Over $157 \mathrm{mph}$ & Over $200 \mathrm{kmh}$ \\
kmh = kilometer per hour, mph = mile per hour. \\
Sources: National Oceanic and Atmospheric Administration. http://www.nhc.noaa.gov/aboutsshws.php; \\
Australian Government Bureau of Meteorology. http://www.bom.gov.au/cyclone/faq/index.shtml
\end{tabular}

Figure 6: Tropical Cyclone Tracks: Simulated Events for Viet Nam and the Philippines (20-year sample)

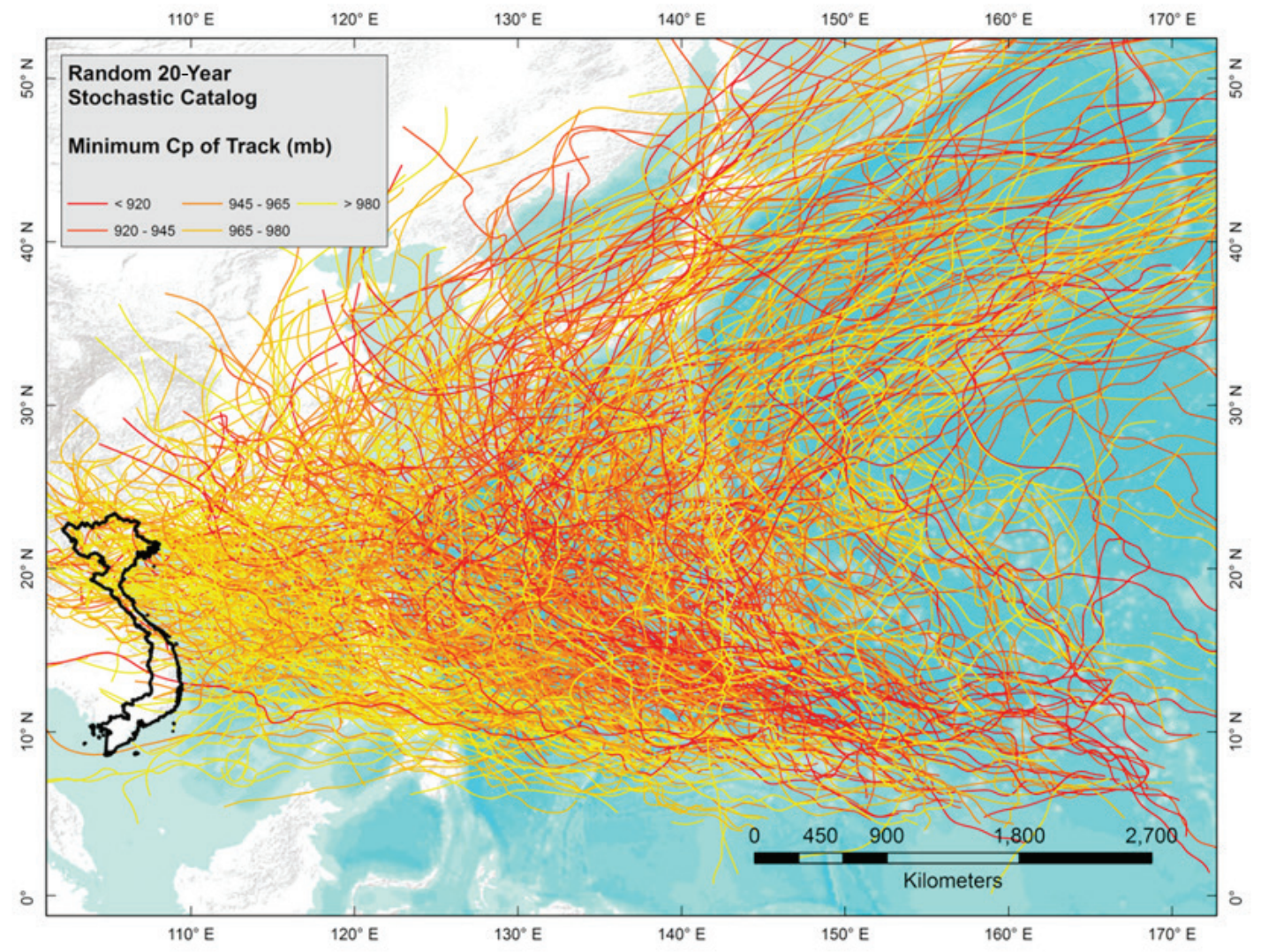

Source: ADB. 
sustained speed of the wind averaged at 1 minute, and basin and subbasin to which the recorded cyclone belongs. IBTrACS data are available for download in several formats, including tabular (csv) and for use with a GIS system (shapefile).

Regional and national data sources. National disaster response, coastal management, or meteorological agencies maintain early warning systems and historic records related to tropical cyclone hazard. Other datasets frequently maintained at the national level include land cover, bathymetric, and topographic data, which are frequently maintained by a country's national mapping agency, and soil maps, which are usually created and maintained by a country's agricultural agency.

At a regional level, an online platform, the Pacific Risk Information System, hosts over 500 datasets in GIS format of national-level hazard and risk information for the 15 countries participating in the Pacific Catastrophe Risk Assessment and Financing Initiative. ${ }^{31}$ These include hazard maps for wind and storm surge for 50-, 100-, 250-, and 500-year return periods in raster format at a resolution of roughly $30 \mathrm{~m}$. The data are visualized on the Pacific Risk Information System platform, which is based on the free and open source GeoNode software, and can be downloaded in a number of formats.

\section{Flood (Riverine)}

Measuring flood hazard. Flood modeling seeks to produce understanding about the potential behavior and intensity of flood events under various rainfall conditions. Hazard is most often represented by depth, extent, and, in some cases, rate of flow of a river for a given rainfall event or return period. An example flood hazard map characterizing flooding by type and severity in Bangladesh is in Figure 7.

Flood modeling is an extremely data-intensive process that requires both detailed projections of future rainfall and high-resolution baseline data characterizing the key hydrological features of the study area for local planning purposes. As a result, most detailed flood hazard assessments tend to be for localized areas, while national-scale flood hazard information is relatively coarse in resolution. Meteorological records are important inputs into rainfall projection models, although the availability and quality of data vary. The Climate Hazards Group InfraRed Precipitation with Station program provides a global historical dataset of precipitation records covering the time period from 1981 to the present. The data are available for download on the Climate Hazards Group InfraRed Precipitation with Station website, ${ }^{32}$ and are intended to support trend analysis of flood and drought hazard modeling. Flow models are based on inputs such as topography, slope, soil, land cover, and river networks and can be developed using software such as GRASS GIS.33 A number of free and open source tools, such as HEC-RAS, ${ }^{34}$ can be used to support flood hazard mapping.

Global data sources. The Dartmouth Flood Observatory at the University of Colorado, Boulder maintains the Global Active Archive of Large Flood Events. ${ }^{35}$ The data contain geo-location, date, and damages (number of people affected and financial losses) for major floods between 1985 and the present. ${ }^{36}$ As of August 2016, there were roughly 4,400 observations in the archive. It is generally considered the most comprehensive global database of flood disasters available.

The 2015 GAR global flood hazard layer is a probabilistic model based on available stream flow data from 8,000 stations around the world. The GAR model then calculates potential discharge at selected points

See Pacific Catastrophe Risk Assessment and Financing Initiative. http://pcrafi.spc.int/

32 See Climate Hazards Group InfraRed Precipitation with Station website. http://chg.geog.ucsb.edu/data/chirps/

33 See GRASS (Geographic Resources Analysis Support System). https://grass.osgeo.org/

34 See United States Army Corp of Engineers. http://www.hec.usace.army.mil/software/hec-ras/

35 See Dartmouth Flood Observatory at the University of Colorado. http://floodobservatory.colorado.edu/Archives

36 The Dartmouth Flood Observatory defines major flooding in a subjective fashion, using criteria such as "significant damage to structures or agriculture, long (decades) reported intervals since the last similar event, and/or fatalities." For more information, see http://floodobservatory.colorado.edu/Archives/ArchiveNotes.html 
Figure 7: Flood Hazard Map for Bangladesh

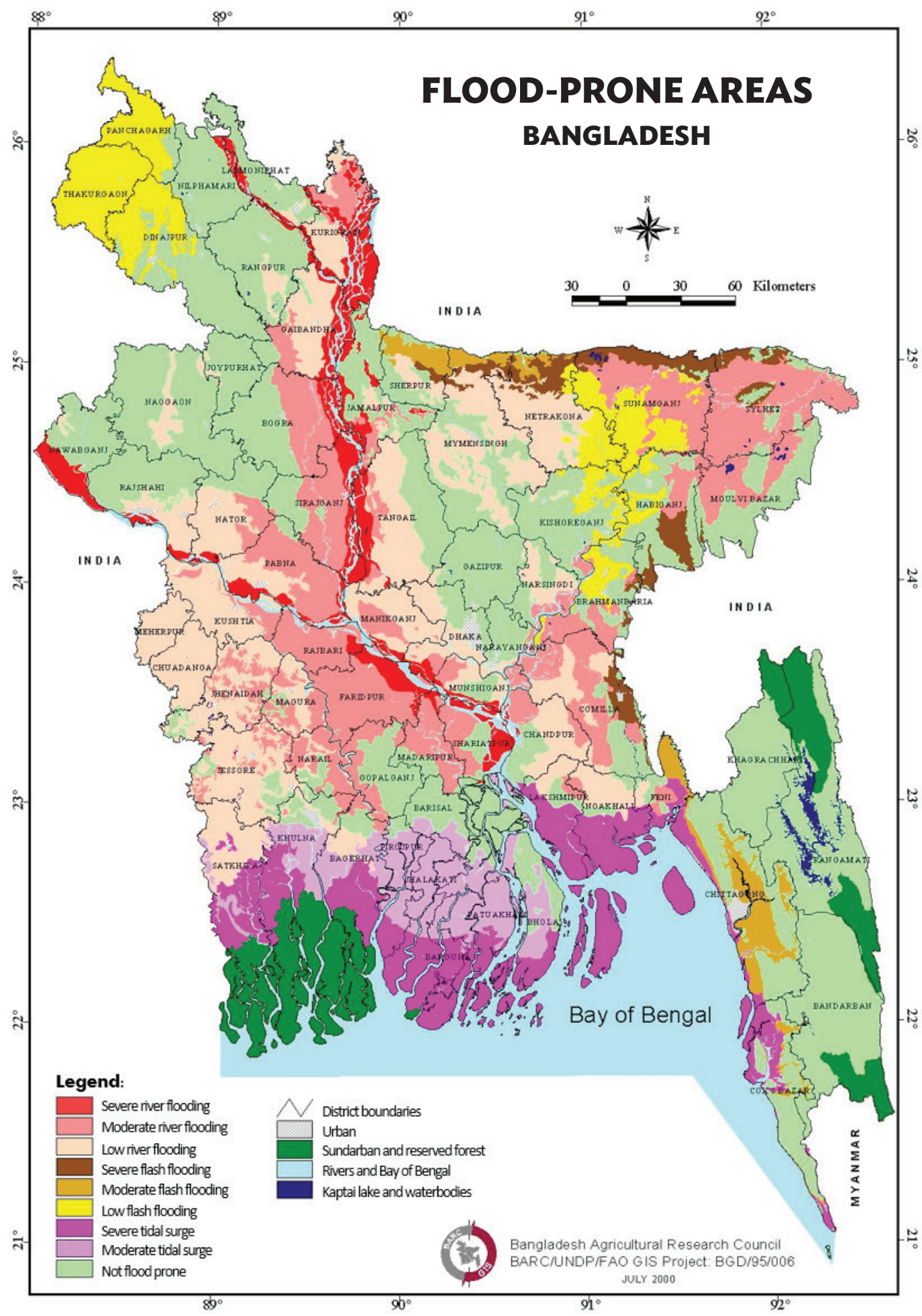

Source: Bangladesh Agricultural Research Council. 2000. BARC/UNDP/FAO FIS Project: BGD/95/006. 
along rivers and the resulting flood extent. Flood hazard is reported at $1 \mathrm{~km}$ resolution for 25-, 50-, 100-, 500-, and 1,000-year return periods. ${ }^{37}$

National data sources. National data sources. National mapping agencies or geological agencies typically have land cover, elevation, and slope datasets while hydrometeorological agencies often maintain precipitation records and models. Soil maps are primarily created and maintained by a country's agricultural agency. Flood hazard modeling has been undertaken for a number of large urban areas in Asia and the Pacific as well. For example, the PetaJakarta project in Indonesia makes real-time flood information for Jakarta available through an interactive web-based mapping platform. It combines reports from the public, river gauge monitors throughout the city, and information sourced from the Jakarta Emergency Management Agency (Badan Penanggulangan Bencana Daerah Provinsi DKI Jakarta). ${ }^{38}$ Raw data can also be downloaded in a number of formats. The extent of data and models is limited, however, in a number of DMCs.

\section{Landslide}

Measuring landslide hazard. Landslides can be either precipitation or seismically induced. As a result, many landslide hazard maps include an indication of earthquake hazard as well as precipitation volume or frequency. These maps show potential areas affected, often categorized into high, medium, or low, or other severity classifications based on either past observed events or modeled potential. The major inputs to landslide hazard models, apart from source, are elevation (slope), soil type, and land cover.

Global data sources. The 2013 GAR created seismically-induced ${ }^{39}$ and precipitation-induced ${ }^{40}$ landslide models. The datasets describe estimated landslide frequency in $1 \mathrm{~km}^{2}$ resolution geotiff, Grid, and ERDAS.

Imagine formats. These data were produced by the International Centre for Geohazards and the Norwegian Geotechnical Institute. They are estimates of annual frequency of landslides based on global datasets that describe slope, lithology, soil moisture, precipitation, seismicity, and land cover. Data are reported as "expected annual probability and percentage of pixel of occurrence of a destructive landslide event $\times 1,000,000,{ }^{\prime 41}$ and should be considered a relative measure.

National data sources. National mapping agencies or geological agencies typically have some land cover, elevation, and slope data. The National Building Research Organisation within the Ministry of Disaster Management in Sri Lanka, for example, has conducted landslide hazard zonation mapping in landslideprone areas of the country. The zonation was conducted through a combination of modeling and field study, and is being used to prioritize disaster risk reduction activities and for other planning purposes. Maps were produced at 1:50,000 and 1:10,000 scales and many are available for download. ${ }^{42}$ Other datasets typically maintained by national governments include precipitation records and models, which are maintained by hydrometeorological agencies; seismic source data, which are maintained by national agencies working on earthquake hazard; and soil maps, which are usually created and maintained by the national agricultural agency. However, as noted earlier, relevant data are limited in a number of DMCs.

37 The results are available at the Global Assessment Report on Disaster Risk Reduction Risk Data Platform. http://risk.preventionweb.net/ capraviewer/main.jsp?countrycode=g15.

38 See Jakarta Emergency Management Agency (Badan Penanggulangan Bencana Daerah Provinsi DKI Jakarta). The platform is located at https://petabencana.id/map/jakarta.

39 Seismically-induced landslide models can be accessed at Global Risk Data Platform. http://preview.grid.unep.ch/index.php?preview $=$ data\&events=landslides\&evcat $=1 \&$ lang=eng

40 Precipitation-induced landslide models can be found at Global Risk Data Platform. http://preview.grid.unep.ch/index.php?preview $=$ data\&events=landslides\&evcat $=2 \&$ lang=eng

41 See Global Risk Data Platform. http://preview.grid.unep.ch/index.php?preview=data\&events=landslides\&evcat=7\&lang=eng

42 See Government of Sri Lanka's National Building Research Organisation. http://www.nbro.gov.lk/ 


\section{Drought}

Measuring drought hazard. Drought is a complex and poorly understood phenomenon. Droughts can be categorized as meteorological, hydrological, agricultural, or socioeconomic and can be measured accordingly. The first three approaches focus on drought as a physical phenomenon, while the latter considers it in terms of supply and demand, tracking the effects of water shortfall as it ripples through socioeconomic systems. ${ }^{43}$

Due to this complexity, there is no single or standard way to measure or assess drought. However, there are a number of measures that are commonly used to monitor drought conditions. The Standardized Precipitation Index (SPI) ${ }^{44}$ compares present and historical precipitation levels to identify areas where rainfall is below historical averages. The IPCC and other international institutions typically rely on the Palmer drought severity index, ${ }^{45}$ wwhich takes into account not only precipitation but also temperature and estimates of soil moisture. Still other approaches rely on satellite imagery technologies to assess vegetation growth against historic norms. The normalized vegetation difference index is one such example ${ }^{46} \mathrm{ADB}$ recently combined analyses of historical precipitation data and vegetation index data to quantify the severity and scope of the 2015-2016 drought in Viet Nam (Box 6).

\section{Box 6: Assessing Drought Severity and Scope in Viet Nam}

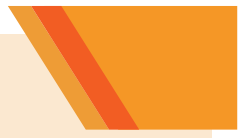

In 2015-2016, Viet Nam experienced one of its most severe drought events in recorded history. Remote-sensing products were applied to quantify the severity and the extent of the drought, focusing on precipitation and vegetation health in six provinces situated east of the Mekong.

First, 35 years of monthly Climate Hazards Group InfraRed Precipitation with Station data from January 1981 to March 2016 were analyzed to determine how likely it was for the region under consideration to experience a given rainfall total based on its historical rainfall record. Rainfall totals that deviated far below the historical average were less likely and would indicate a more severe event. This analysis indicated that, from April 2015 to March 2016, the area under investigation experienced 1,436 millimeters of rainfall, less than its annual total in $94 \%$ of years, equivalent to a 1-in-17-year event. As such, 2015-2016 rainfall totals represented an infrequent and severe drought event in the context of Viet Nam's recent rainfall history.

Second, a standard vegetation index (SVI) was applied to measure the relative state of vegetation cover in the provinces under consideration relative to historical values for the period 2000-2015. Low SVI values (which can result from factors such as low moisture, flooding, and temperature extremes) indicate poor vegetative health, while high SVI values indicate good growing conditions. SVIs were estimated for nine dates in the first half of 2016. The analysis found that SVI values were normal until early March, but were poor beyond that. It was noted in the report that SVIs show the state of vegetation regardless of growing conditions - for instance, irrigation, water management strategies, and land use - and that it is not unlikely that irrigated crops could grow despite a meteorological drought in reservoir-rich Viet Nam.

Source: B. Coerver. 2016. Drought Analysis, South Vietnam, 2016. Manila and Delft: Asian Development Bank and UNESCO-IHE Institute for Water Education.

43 D.A. Wilhite and M.H. Glantz. 1985. Understanding the Drought Phenomenon: The Role of Definitions. Water International.10(3). pp. 111-120.

44 See United States National Oceanic and Atmospheric Administration. https://www.ncdc.noaa.gov/oa/climate/research/prelim/ drought/spi.html

45 See National Center for Atmospheric Research. https://climatedataguide.ucar.edu/climate-data/palmer-drought-severity-index-pdsi

46 See NASA Earth Observations. http://neo.sci.gsfc.nasa.gov/view.php?datasetld=MOD13A2_M_NDVII 
Global data sources. The 2013 GAR contains data on the occurrence of global droughts between 1980 and 2001, based on the SPI. The data are available for download in GIS (shapefile) format. ${ }^{47}$

The Global Integrated Drought Monitoring and Prediction System at the University of California, Irvine is an online source for near real-time information and predictions about drought worldwide. The platform uses multiple indicators and indexes of drought, including precipitation and soil moisture indexes. Data are available in the form of interactive maps as well as downloadable tables. ${ }^{48}$

Regional and national data sources. Most drought indexes are produced and maintained by international agencies. Few governments, with the exception of larger countries like India, ${ }^{49}$ host national drought early warning systems. Historical rainfall records, which in some cases can be used to calibrate drought indexes or estimate recurrence, are typically maintained by government meteorological agencies.

47 See Global Risk Data Platform. http://preview.grid.unep.ch/index.php?preview=data\&events=droughts\&evcat=1\&lang=eng

48 See Global Integrated Drought Monitoring and Prediction System at the University of California, Irvine. http://drought.eng.uci. edu

49 See Government of India, Ministry of Agriculture and Farmers Welfare ,Department of Agriculture Cooperation and Farmers Welfare. http://agricoop.nic.in/divisions 


\section{Other Data Sources}

Climate Services for Resilient Development Partnership. ADB is a founding member of the Climate Services for Resilient Development partnership. This partnership, which also includes the governments of the United Kingdom and the United States, the Inter-American Development Bank, the American Red Cross, the Environmental Systems Research Institute (commonly recognized by its acronym Esri), Google, and the Skoll Global Threats Fund, was launched in June 2015 to "provide needed climate services - including actionable science, data, information, tools, and training - to developing countries that are working to strengthen their national resilience to the impacts of climate change." 50 Data related to both extreme weather events and long-term stressors are being made available as part of the partnership. Bangladesh was the first Asian country to benefit from this program. For more information, contact ADB's Climate Change and Disaster Risk Management Division.

Open Data for Resilience Initiative (OpenDRI). The World Bank's Global Facility for Disaster Reduction and Recovery launched the OpenDRI in 2011 to harness the philosophy and practices of "the global open data movement to the challenges of reducing vulnerability to natural hazards and the impacts of climate change." ${ }^{51}$ OpenDRI has partnered with regional organizations and national governments in Asia to launch data sharing platforms (such as the Sri Lanka Disaster Risk Information Platform, http://riskinfo.lk/; Government of Nepal GeoPortal, http://drm.moha.gov.np/; and the Pacific Catastrophe Risk Assessment and Financing Initiative, http://pcrafi.spc.int), to support community mapping projects related to disaster risk reduction (http://www.opencitiesproject.org/), and to build tools to communicate complex risk information to diverse stakeholder audiences (http://inasafe.org/). More information about available data through OpenDRI projects can be found at https://opendri.org

Pacific Disaster Center. The Pacific Disaster Center (PDC) works across Asia in the area of disaster and climate risk information. PDC is a nonprofit scientific and technical organization, based in Hawaii, that works both at national and regional levels to support governments through the conduct of disaster risk assessment, the creation of tools for analyzing or communicating risk data, and the provision of guidance into strategies for building resilience. More information about PDC's work and the data tools and products it provides can be found at http://www.pdc.org/

DesInventar. DesInventar provides tools and a methodology designed to help governments create and maintain historical disaster impact catalogs, including small localized disasters as well as major events. As discussed in section 2 , these catalogs can provide an important input into natural hazard models when properly maintained and updated. As of August 2016, DesInventar was active in 91 countries around the world, including 24 of ADB's DMCs. More information about Deslnventar can be found at http://www. desinventar.org/en/

Shuttle Radar Topography Mission. The Shuttle Radar Topography Mission is an international program led by the Government of the United States that captured high-resolution DEMs for most of the earth, excluding Antarctica and the northernmost latitudes, in 2000. DEMs, which

\footnotetext{
50 The White House, Office of the Press Secretary. 2015. Fact Sheet: Launching a Public-Private Partnership to Empower ClimateResilient Developing Nations. https://www.whitehouse.gov/the-press-office/2015/06/09/fact-sheet-launching-public-privatepartnership-empowerclimate-resilien (published 9 June 2015).

51 Open Data for Resilience Initiative. https://opendri.org/
} 
describe the topography of a region, are fundamental inputs to many kinds of natural hazard information..$^{52}$ As of 2017, scientists were re-analyzing radar data to improve precision and other quality aspects. More information about the program can be found at http://www2.jpl.nasa.gov/srtm/

EM-DAT International Disasters Database. The EM-DAT International Disasters Database is a global historic catalog containing information on over 18,000 natural and technological disaster events from the year 1900 to the present. The dataset is maintained by the Centre for Research on the Epidemiology of Disasters at the Université Catholique de Louvain in Brussels, Belgium. For each disaster event, the EMDAT database stores information on the location, date, and the human and economic impacts. Some data, including country profiles and summary tables, are available for direct download. Requests for access to the full database are granted on a case-by-case basis. The EM-DAT database can be accessed at http:// www.emdat.be/

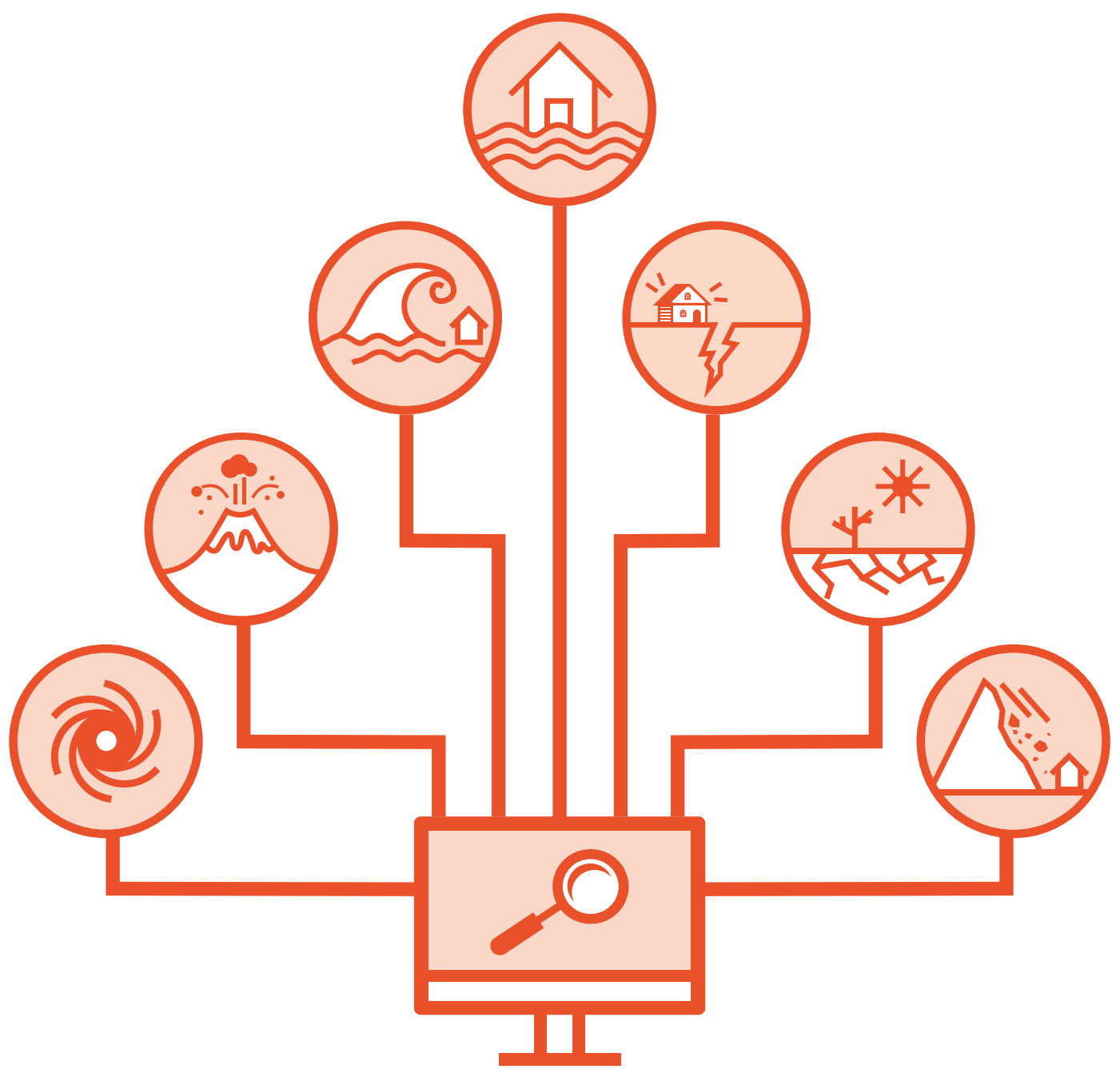

52 The data are available for download in GIS format at $30 \mathrm{~m}$ resolution from the United States Geological Survey at http://eros. usgs.gov 


\section{Recommendations for Managing Natural Hazard Data Created by ADB}

$A D B$ invests significant energy and resources into creating natural hazard information, and such investments are likely to increase as disaster risk management and climate change agendas gain greater prominence within ADB's overall project portfolio. There is a great deal of diversity both between and within ADB's operations departments with respect to practices surrounding the creation, management, and use of this natural hazard information. Several teams have high internal capacity in these regards, while others have expressed significant demand for greater technical support. This final section of the practical guide provides brief summary recommendations on how ADB could approach the creation and management of natural hazard data and streamline approaches across sectors and regions.

Creation of a spatial data repository within ADB. ADB projects invest in significant amounts of spatial data. Currently, there is no system or repository in place that would ensure that these data are available to future ADB projects or governments of client countries once these projects have been completed. $A D B$ could host spatial data management platforms to catalog and store data created with its support, along with associated metadata, at comparatively limited cost relative to that of data creation. Such an effort would require not just the development of technical and administrative infrastructure within ADB to host and maintain data, but also outreach to project teams to make them aware of the resources and to encourage them to submit data produced by their projects to the platform. Data should also be placed on existing external data-sharing platforms.

Build local capacity within governments to manage spatial data. The most important users of natural hazard information are the governments and citizens of ADB's DMCs. It is important, therefore, that there are management plans in place within DMC national mapping and other agencies to maintain and update hazard data produced with ADB support and to secure access. In many countries, such work can be aligned with wider efforts to build national spatial data infrastructure. ${ }^{53}$ In other cases, free and open source data-sharing platforms like GeoNode ${ }^{54}$ can be deployed within relevant ministries in support of open data and data management efforts or to establish metadata clearing houses. Projects that seek to support data management work within countries should attend to institutional arrangements related to data management and sharing as well as technical needs, including in the preparation of terms of reference.

Support open data efforts. In many countries, informal or nonexistent data sharing policies between various government agencies responsible for creating and managing natural hazard data place severe constraints on access to existing hazard data. This dynamic contributes to situations where DRM decisionmaking is based on incomplete information, or resources are wasted as a result of duplication of efforts, with the recreation of hazard data that already exists. Open data is increasingly recognized around the world as both an effective solution to data sharing challenges and good practice.

ADB projects can promote the adoption of open data approaches and policies among government entities. Where possible, connecting such projects in the climate and disaster space to wider initiatives will help garner support for these efforts. OpenDRI, which works on open data issues related to climate and disaster risk information, defines data as being open when they are technically and legally open. Technically open refers to the storage of data in a common data format (section 4) that allows the data to be manipulated

\footnotetext{
53 For an example and more information, see Federal Geographic Data Committee. https://www.fgdc.gov/nsdi/nsdi.html

54 See GeoNode. http://geonode.org
} 
or analyzed in other software packages. For example, images of flood maps or pdf documents are not considered technically open. CSV files or data formatted for GIS software could be. Legally open refers to the terms of use, or license, under which a dataset is released. There are a number of existing open data licenses, including the suite of Creative Commons ${ }^{55}$ licenses and the Open Database License. ${ }^{56}$ In many countries, open data initiatives already exist through the Open Government Partnership or similar programs. Relevant data-sharing requirements could be included within standard ADB terms of reference and contracts for projects that produce data, as discussed in further detail below.

Build local scientific capacity. Projects that invest in the creation of natural hazard data should also contribute to the development of local scientific capacity to utilize and further update those data. In too many cases, natural hazard and disaster risk assessment projects rely exclusively on international consultants and firms. This overlooks the existence of national experts as well as opportunities to contribute to the development of local capacity. There are many ways to contribute to the development of the local scientific community. Beyond seeking to hire locals, projects can also support local peer review processes of risk assessment results, organize dissemination workshops in ways that reach broad audiences, engage universities and their students, and employ other strategies to engage and contribute to the strengthening of the local scientific community.

Develop common language for terms of reference across ADB. Project officers require information and support relating to disaster risk assessments and spatial data management. In addition to the series of practical guides that this document is a part of, it could also be beneficial to develop common language for terms of reference and checklists to assist project officers, and to establish standards for data creation and management across the institution. Topics covered could include data standards, guidance on data formats, copyright and other licensing concerns, storage and maintenance strategies, and other issues as relevant.

Preparation of natural hazard data availability profiles for DMCs. At present, ADB officers lack a comprehensive assessment of the availability of natural hazard data for the DMCs in which they work. As a result, teams are unable to incorporate such information into their project design or are forced to expend significant time and resources collecting it. To remedy this situation, ADB could draw together national-level analyses of natural hazards and disaster and climate risk, the availability of and key gaps in hazard information, and lists of key government and scientific organizations working in these domains for countries where ADB is active. As an example, data availability in Nepal is reviewed in the appendix.

55 See Creative Commons. https://creativecommons.org/licenses/

56 See Open Data Commons Open Database License. http://opendatacommons.org/licenses/odbl/ 


\section{Appendix}

\section{COUNTRY CASE STUDY: NATURAL HAZARD DATA IN NEPAL}

\section{A. Introduction}

This country natural hazard data report provides a short overview of the status and availability of hazard data in Nepal as of September 2015. It has been prepared as a sample piece to provide guidance to the Asian Development Bank (ADB) teams that are seeking to collate and access natural hazard and disaster risk information at a country level for use in the preparation of country partnership strategies and projects. The report is meant as a starting point and does not contain recommendations on how to incorporate disaster or climate risk concerns into ADB's country partnership strategies and projects, or obviate the need to conduct proper risk and vulnerability assessments.

\section{B. Nepal Natural Hazard Overview}

Located at the convergence of the Indian and Tibetan (Eurasian) plates that gives rise to the Himalayan mountains, Nepal faces severe threat from multiple hazards, including earthquakes, floods, and landslides. Its capital city, Kathmandu, has been categorized as one of the most at-risk cities in the world from earthquakes.' Weak governance and poor construction techniques increase the country's vulnerability. ${ }^{2}$ Analysis of past disaster events during 1971-2011 shows that, apart from epidemics, key natural hazards that take the largest toll of life every year are landslides, floods, fires, thunderstorms, earthquakes, cold waves, and drought. ${ }^{3}$ Nepal's National Strategy for Disaster Risk Management considers floods, landslides, fire, earthquakes, and drought as principal hazards in terms of their extent and frequency of occurrence, as well as spread and intensity. ${ }^{4}$

Many areas of Nepal, in particular the flat lands in Southern Terai, valleys, and midhill river valleys, are flood-prone. Flooding affected almost 4 million people between 1971 and 2011. ${ }^{5}$ Landslides, induced by both precipitation and seismicity, are another significant threat across central and northern Nepal. All of Nepal is susceptible to drought, the most severe risk being in the western areas of the country during premonsoon and winter seasons. Increased variation of patterns in rainfall caused by climate change will increase drought, floods, forest fires, and precipitation-induced landslides hazard.

On 25 April 2015, a 7.8 magnitude earthquake struck central Nepal. The quake and aftershocks killed almost 9,000 people and destroyed upwards of 500,000 homes. The postdisaster needs assessment estimates the economic damages at $\$ 7$ billion, equivalent to about a third of the country's gross domestic product for fiscal year 2013-2014. The housing sector accounted for the majority of economic losses, but education, transport, and cultural heritage were also severely impacted. Rural areas in particular were affected. The recovery process, now under way, will require years to complete.

\footnotetext{
Government of Nepal, Ministry of Home Affairs. 2011. Nepal Disaster Report 2011: Policies, Practices and Lessons. http://www. preventionweb.net/files/29915_ndr2011.pdf

2 Government of Nepal. 2015. Post Disaster Needs Assessment Executive Summary. http://reliefweb.int/sites/reliefweb.int/files/ resources/PDNA_Executive_Summary_new.pdf

3 DesInventar Disaster Information Management System. Nepal. http://www.desinventar.net/Des/nventar/profiletab. jsp?countrycode=npl\#more_info

4 Government of Nepal. 2009. National Strategy for Disaster Risk Management. http://www.un.org.np/sites/default/files/ report/2010-08-06-nsdrm-in-eng-2009.pdf

5 DesInventar Disaster Information Management System. Nepal. http://www.desinventar.net/Deslnventar/profiletab.
} jsp? countrycode=npl 


\section{Review of Data Availability by Major Natural Hazard Type}

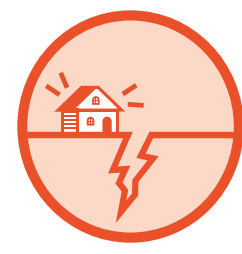

\section{Earthquake}

Seismic phenomena within the Kathmandu Valley has been examined in several major reports, but there is need for more detailed study, especially in the southern and western parts of the country, where little research has been conducted on site effects, liquefaction potential, or attenuation parameters. The Nepal National Seismological Centre (NSC) ${ }^{6}$ within the Department of Mines and Geology is the government agency responsible for research and monitoring of seismic activity and hazard in Nepal.

Natural hazard maps. The NSC produced a national seismic map, measured in peak ground acceleration (PGA) in 2002.'The map provides a coarse overview of earthquake hazard at a national level. It is available for purchase in digital or hard copy from their offices at 1:1,500,000 scale. In 2010, the Ministry of Home Affairs (MOHA) facilitated the preparation of a national multihazard risk assessment that relied on the NSC dataset to produce a number of seismic hazard assessments at the national scale. Key datasets are available at MOHA's geoportal. ${ }^{8}$ Detailed data are available upon request from the Asian Disaster Preparedness Center (ADPC).

Historical catalog. The NSC maintains a digital record of earthquake activity from 1994 to the present, containing the time and date, latitude-longitude coordinates of the epicenter, and the magnitude of the shaking. ${ }^{9}$ The complete record can be purchased from their offices. Records for recent years are available at http://www.seismonepal.gov.np/index.php?action=earthquakes\&show=past

Monitoring network. The NSC has a network of 21 short-period seismic stations, 7 accelerometers, and 29 GPS locations around Nepal. However, not all stations are currently functional and the NSC was unable to collect usable data during the 25 April 2015 Gorkha earthquake.

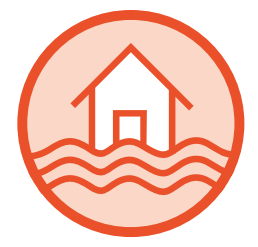

\section{Flood}

Natural hazard maps. While a number of flood hazard assessments have been completed, some parts of the country are not covered. In addition, these flood assessments are often not conducted in a consistent fashion, or made available beyond the project that created them.

The 2010 multihazard risk assessment of Nepal, facilitated by MOHA and prepared by ADPC, created flood hazard maps for seven river basins: Babai, Bagmati, Rapti, Kamala, Kankai, Tinau, and Narayani. They show flood extent and depth for 10-, 25-, 50-, 100-, and 500-year return periods. These maps were based on national and global data from sources including the Department of Hydrology and Meteorology (river discharge), Department of Survey (elevation, land use, river network and catchments, and land cover), and National Aeronautics and Space Administration Shuttle Radar Topography Mission (elevation). Key datasets are available at MOHA's geoportal (footnote 8). Detailed data are available upon request from ADPC.

The Department of Water Induced Disaster Management, Ministry of Irrigation, with support from ADB, prepared flood hazard maps incorporating future climate change scenarios for 25 priority river basins in the Terai region of Nepal. The basins are Biring, Kankai, Kamal Baniyani, Mawa Ratuwa, Bakraha, Chisang, Budhi, Khando, Balan, Gagan, Jalad, Aurahi/Bighi, Jhim, Lakandehi, Lal Bakeya, East Rapti, Narayani, Banganga, West Rapti, Karnali, Kandra, Khutia, Mohana, Dodha, and Chaudhar. The maps were modeled based on cross-sectional

\footnotetext{
See Government of Nepal's National Seismological Centre. http://www.seismonepal.gov.np/

See United States Geological Survey. http://earthquake.usgs.gov/learn/glossary/?term=acceleration

The MOHA geoportal is at http://drm.moha.gov.np/

See United States Geological Survey. http://earthquake.usgs.gov/learn/glossary/?term=Richter\%20scale
} 
surveys, digital elevation models, and high-resolution satellite orthoimages, and use historical precipitation and flow data. The flood hazard maps were completed in 2016. ${ }^{10}$

The World Bank financed DHI to conduct a flood hazard and risk assessment of the lower Koshi River Basin between Chatara and the border between Nepal and India in 2015.

In 2011, the International Centre for Integrated Mountain Development (ICIMOD) published a study of potential sites of glacial lake outburst flood." As a result of warming temperatures, glacial melt in the Himalayas is leading to the creation of new mountain lakes. Over 14 events where these lakes burst their catchments, leading to catastrophic rapid-onset flooding, have been recorded in Nepal. Twenty one lakes were identified as having high potential for overflow, of which three were subject to detailed field study ${ }^{12}$ Detailed data from this study are available upon request from ICIMOD.

Monitoring network. The Nepal Department of Hydrology and Meteorology (DHM) maintains a national network of 282 meteorological stations and 51 hydrological stations. ${ }^{13}$ River flow and rainfall data are available from the department, ${ }^{14}$ though limitations in the quality, inadequate network density to capture variations between different watersheds, and maintenance of the monitoring equipment may lead to inconsistencies or inaccuracies in the results.

\section{Landslide}

Natural hazard maps. The 2010 MOHA national multihazard risk assessment produced both seismicand precipitation-induced landslide national hazard maps. Data are at 1 square kilometer $\left(\mathrm{km}^{2}\right)$ resolution and available upon request from ADPC. Landslide hazard is presented as a susceptibility index, and based upon global datasets describing land cover, elevation and/or slope, soil moisture, and lithology. Trigger information is based on precipitation data from the Global Precipitation Climatology Centre and earthquake data provided by the Norwegian Geotechnical Institute. Authors note that the quality of the soil and land cover information limit the overall reliability of these landslide hazard information. The outputs, while useful for a countrywide overview, are coarse in resolution and do not replace the need for local site assessment for specific projects. Sectoral departments such as roads, irrigation, and hydropower carry out landslide assessment in areas that have risk to physical infrastructure. Data from these assessments are not available beyond the relevant individual projects.

Historical catalog. The Department of Mines and Geology has collected limited data toward a landslide inventory for parts of the country that is available upon request.

Earthquakes without Frontiers published an online map of landslides following the April 2015 earthquake, ${ }^{15}$ with access to the data ${ }^{16}$ ICIMOD has also conducted a number of postearthquake studies on landslide susceptibility. ${ }^{17}$

10 ADB. 2016. Water Resources Project Preparatory Facility Package 3: Flood Hazard Mapping and Preliminary Preparation of Flood Risk Management Projects. Consultant's report. Manila (Grant 0299-NEP).

11 ICIMOD. 2011. Glacial Lakes and Glacial Lake Outburst Floods in Nepal. Kathmandu. http://www.icimod.org/dvds/201104_GLOF/ reports/final_report.pdf

12 Data are available at ICIMOD Mountain Portal at http://geoportal.icimod.org/

13 See Government of Nepal's Department Of Hydrology and Meteorology. http://www.dhm.gov.np/hydrological-station/

14 See Government of Nepal's Department Of Hydrology and Meteorology. http://www.hydrology.gov.np/new/bull3/index.php/ hydrology/home/mai

15 See AGU Blogosphere. http://blogs.agu.org/landslideblog/2015/07/01/an-updated-landslide-density-map-from-thenepal-earthquakes-fromthe-ewf-project/

16 See Earthquakes without Frontiers. http://ewf.nerc.ac.uk/wp-content/uploads/2015/06/ Nepal_LS_LowRes_Col1.jpg

17 See International Centre for Integrated Mountain Development. http://www.icimod.org/?q=17923 


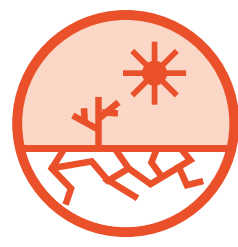

\section{Drought}

Natural hazard maps. The 2010 MOHA national multihazard risk assessment also produced national drought susceptibility maps. The precipitation data come from the records of 40 meteorological stations around the country over a time frame of more than 30 years, supplemented with climatic data from the Department of Hydrology and Meteorology and other sources. The susceptibility maps rate the percent chance of various regions of the country experiencing drought in a given season (winter, premonsoon, monsoon, postmonsoon) each year. Data are available upon request from ADPC.

Climate change projections. In 2013, the DHM, with support from ADB, produced downscaled future climate projections using a dynamic downscaling technique. ADPC, jointly with BBCR Norway, ITC Netherlands, and TERI India, provided technical support to the modeling work. Three key models, namely PRECIS, RegCM4, and WRF, have been used for nine different scenarios to produce high-resolution (12, 20, and 25 kilometers) future climate scenarios. The Nepal Climate Data portal can be accessed at www. dhm.gov.np/dpc/

In 2012, the International Water Management Institute (IWMI) with support from ADB prepared climate change and vulnerability mapping in watersheds in the middle and high mountains of Nepal. This report identified and prioritized subbasins and watersheds in the middle and high mountains of Nepal that are significantly vulnerable to climate change. Temperature and rainfall risk, ecology, landslides and/or floods, drought, and food surpluses or deficiencies were analyzed using historical records and climate change data derived from the existing regional climate model. The resulting data and maps are available from IWMI at https://www.adb.org/sites/default/files/project-document/73085/44214-023-nep-tacr.pdf 
Table A1: Major Studies and Reports

\begin{tabular}{|c|c|c|c|c|c|}
\hline Title & Year & Author & $\begin{array}{l}\text { Natural } \\
\text { Hazards } \\
\text { Covered }\end{array}$ & $\begin{array}{l}\text { Spatial } \\
\text { Extent }\end{array}$ & Available at \\
\hline $\begin{array}{l}\text { Kathmandu Valley } \\
\text { Earthquake Risk } \\
\text { Management Project }\end{array}$ & 2000 & $\begin{array}{l}\text { National } \\
\text { Society for } \\
\text { Earthquake } \\
\text { Technology } \\
\text { and } \\
\text { GeoHazards } \\
\text { International }\end{array}$ & Earthquake & $\begin{array}{l}\text { Kathmandu } \\
\text { Valley }\end{array}$ & $\begin{array}{l}\text { http://www.adpc.net/igo/ } \\
\text { category/ID187/doc/2013- } \\
\text { IPGs38-ADPC-Kathmandu__ } \\
\text { Valley_Earthquake_Risk_- } \\
\text { Management_Project.pdf }\end{array}$ \\
\hline $\begin{array}{l}\text { Earthquake Disaster } \\
\text { Mitigation in the } \\
\text { Kathmandu Valley }\end{array}$ & 2002 & $\begin{array}{l}\text { Japan } \\
\text { International } \\
\text { Cooperation } \\
\text { Agency }\end{array}$ & Earthquake & $\begin{array}{l}\text { Kathmandu } \\
\text { Valley }\end{array}$ & $\begin{array}{l}\text { http://flagship2.nrrc.org. } \\
\text { np/sites/default/files/ } \\
\text { knowledge/JICA\%20-\%20 } \\
\text { The\%20study\%20on\%20 } \\
\text { Earthquake\%20Disaster\%20 } \\
\text { Mitigation_Vol1.pdf }\end{array}$ \\
\hline $\begin{array}{l}\text { Water Induced } \\
\text { Disasters, Flood } \\
\text { Hazard Mapping, and } \\
\text { Koshi Flood Disaster } \\
\text { of Nepal }\end{array}$ & 2009 & $\begin{array}{l}\text { Japan } \\
\text { International } \\
\text { Cooperation } \\
\text { Agency }\end{array}$ & Flood & $\begin{array}{l}\text { Koshi River } \\
\text { Basin }\end{array}$ & $\begin{array}{l}\text { http://www.preventionweb. } \\
\text { net/files/9333_ } \\
\text { progressreport2009nepal1.pdf }\end{array}$ \\
\hline $\begin{array}{l}\text { Nepal Disaster Report } \\
\text { 2009: Hazardscape } \\
\text { and Vulnerability }\end{array}$ & 2009 & $\begin{array}{l}\text { Ministry of } \\
\text { Home Affairs }\end{array}$ & Multihazard & National & $\begin{array}{l}\text { http://www.np.undp.org/ } \\
\text { content/dam/nepal/docs/ } \\
\text { reports/drm/UNDP_NP_- } \\
\text { Nepal\%20Disaster\%20 } \\
\text { Report\%202009_The\%20 } \\
\text { Hazardscape\%20and\%20 } \\
\text { Vulnerability.pdf }\end{array}$ \\
\hline $\begin{array}{l}\text { Nepal Hazard Risk } \\
\text { Assessment }\end{array}$ & 2010 & $\begin{array}{l}\text { Asian } \\
\text { Disaster } \\
\text { Preparedness } \\
\text { Center }\end{array}$ & Multihazard & National & $\begin{array}{l}\text { http://www.gfdrr.org/sites/ } \\
\text { gfdrr.org/files/documents/ } \\
\text { Nepal_HazardAssessment_- } \\
\text { Part1.pdf }\end{array}$ \\
\hline $\begin{array}{l}\text { Mainstreaming } \\
\text { Disaster Risk } \\
\text { Reduction in } \\
\text { Megacities: A Pilot } \\
\text { Application in } \\
\text { Metro Manila and } \\
\text { Kathmandu }\end{array}$ & 2010 & $\begin{array}{l}\text { Earthquake } \\
\text { and } \\
\text { Megacities } \\
\text { Initiatives }\end{array}$ & Earthquake & $\begin{array}{l}\text { Kathmandu } \\
\text { Valley }\end{array}$ & $\begin{array}{l}\text { http://preventionweb.net/ } \\
\text { go/14837 }\end{array}$ \\
\hline $\begin{array}{l}\text { Glacial Lakes and } \\
\text { Glacial Lake Outburst } \\
\text { Floods in Nepal }\end{array}$ & 2011 & $\begin{array}{l}\text { International } \\
\text { Center for } \\
\text { Integrated } \\
\text { Mountain } \\
\text { Development }\end{array}$ & $\begin{array}{l}\text { Glacial lake } \\
\text { outburst } \\
\text { floods }\end{array}$ & National & $\begin{array}{l}\text { http://www.icimod.org/ } \\
\text { dvds/201104_GLOF/reports/ } \\
\text { final_report.pdf }\end{array}$ \\
\hline $\begin{array}{l}\text { Nepal: Building } \\
\text { Climate Resilience } \\
\text { of Watersheds in } \\
\text { Mountain Eco- } \\
\text { Regions }\end{array}$ & 2012 & $\begin{array}{l}\text { International } \\
\text { Water } \\
\text { Management } \\
\text { Institute }\end{array}$ & $\begin{array}{l}\text { Climate, } \\
\text { drought, } \\
\text { landslide, } \\
\text { food security }\end{array}$ & $\begin{array}{l}\text { Middle } \\
\text { and high } \\
\text { mountain } \\
\text { areas }\end{array}$ & $\begin{array}{l}\text { https://www.adb.org/ } \\
\text { sites/default/files/project- } \\
\text { document/73085/44214-023- } \\
\text { nep-tacr.pdf }\end{array}$ \\
\hline
\end{tabular}


Table A2: Organizations with Roles in Natural Hazard Information

\section{Organization}

Department of Mines and Geology

Department of Hydrology and Meteorology

National Seismological Center, Department of Mines and Geology

Department of Soil Conservation and Watershed Management, Ministry of Forest and Soil Conservation

Department of Irrigation, Ministry of Irrigation

Department of Survey

Department of Water Induced Disaster Prevention

National Society for Earthquake Technology

International Center for Integrated Mountain Development

Water and Energy Commission Secretariat
Lithology, soil profiles

\section{Data Types}

Rainfall, river flow, temperature data, satellite-based precipitation data, flood forecasting, flood hazard maps of select river basins

Earthquake hazard, strong motion, global positioning system, accelerometer, historical seismic activity, fault mapping

Soil maps, forest cover, flood hazard maps of select rivers and watersheds. LIDAR Image for forested area in the country (Ministry of Forest and Soil Conservation)

Flood hazard maps of select river basins, LIDAR images for large scale irrigation command areas

Topographic maps, land cover

Flood hazard maps, local flood and landslide studies

Various seismic hazard and vulnerability assessments

Various flood, landslide, forest fire and glacial lake outburst flood studies

Flood hazard map of major river basins

Source: ADB. 
Table A3: Other Natural Hazard Data Sources

\begin{tabular}{|c|c|c|c|}
\hline Name & Description & Owner & Link \\
\hline $\begin{array}{l}\text { Government of Nepal } \\
\text { GeoPortal }\end{array}$ & $\begin{array}{l}\text { Geographic } \\
\text { information system } \\
\text { base and earthquake } \\
\text { data layers }\end{array}$ & $\begin{array}{l}\text { Ministry of Home } \\
\text { Affairs }\end{array}$ & http://drm.moha.gov.np \\
\hline DesInventar Nepal & $\begin{array}{l}\text { Historical multihazard } \\
\text { impact catalog } \\
\text { covering 1971-2011 }\end{array}$ & $\begin{array}{l}\text { National Society } \\
\text { for Earthquake } \\
\text { Technology - } \\
\text { Nepal }\end{array}$ & $\begin{array}{l}\text { http://www.desinventar. } \\
\text { net/DesInventar/profiletab. } \\
\text { jsp?countrycode=npl }\end{array}$ \\
\hline Mountain Geoportal & $\begin{array}{l}\text { Geographic } \\
\text { information system } \\
\text { data layers }\end{array}$ & $\begin{array}{l}\text { International } \\
\text { Center for } \\
\text { Integrated } \\
\text { Mountain } \\
\text { Development }\end{array}$ & http://geoportal.icimod.org \\
\hline $\begin{array}{l}\text { Forest Fire Detection } \\
\& \text { Monitoring System } \\
\text { in Nepal }\end{array}$ & $\begin{array}{l}\text { Web portal and short } \\
\text { message service } \\
\text { subscription service }\end{array}$ & $\begin{array}{l}\text { International } \\
\text { Center for } \\
\text { Integrated } \\
\text { Mountain } \\
\text { Development }\end{array}$ & http://www.icimod.org/?q=7038 \\
\hline
\end{tabular}




\section{Natural Hazard Data}

A Practical Guide

Asia and the Pacific faces significant exposure to every major type of geophysical and weather-related hazard, and the countries in the region consistently rank among the most at risk from the human and economic impacts of natural hazards.

The purpose of this practical guide is to provide Asian Development Bank (ADB) project officers with a basic understanding of natural hazards, the nature and purpose of hazard mapping and disaster risk assessments, and the availability and sources of related data and information in taking disaster risk into account in project design. It aso provides guidance to ADB staff on the identification and application of data for use in integrating disaster risk considerations in country partnership strategies and individual projects.

\section{About the Asian Development Bank}

ADB's vision is an Asia and Pacific region free of poverty. Its mission is to help its developing member countries reduce poverty and improve the quality of life of their people. Despite the region's many successes, it remains home to a large share of the world's poor. ADB is committed to reducing poverty through inclusive economic growth, environmentally sustainable growth, and regional integration.

Based in Manila, ADB is owned by 67 members, including 48 from the region. Its main instruments for helping its developing member countries are policy dialogue, loans, equity investments, guarantees, grants, and technical assistance. 